Atmos. Chem. Phys., 19, 10961-10980, 2019

https://doi.org/10.5194/acp-19-10961-2019

(C) Author(s) 2019. This work is distributed under

the Creative Commons Attribution 4.0 License.

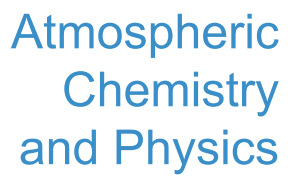

(c) (P)

\title{
Comparison of two automated aerosol typing methods and their application to an EARLINET station
}

\author{
Kalliopi Artemis Voudouri ${ }^{1}$, Nikolaos Siomos ${ }^{1}$, Konstantinos Michailidis $^{1}$, Nikolaos Papagiannopoulos ${ }^{2,3}$, \\ Lucia Mona $^{2}$, Carmela Cornacchia ${ }^{2}$, Doina Nicolae ${ }^{4}$, and Dimitris Balis ${ }^{1}$ \\ ${ }^{1}$ Laboratory of Atmospheric Physics, Physics Department, Aristotle University of Thessaloniki, Thessaloniki, Greece \\ ${ }^{2}$ Consiglio Nazionale delle Ricerche, Istituto di Metodologie per l'Analisi Ambientale (CNR-IMAA), Tito Scalo (PZ), Italy \\ ${ }^{3}$ CommSensLab, Dept. of Signal Theory and Communications, Universitat Politècnica de Catalunya, Barcelona, Spain \\ ${ }^{4}$ National Institute of R\&D for Optoelectronics (INOE2000), Magurele, Romania
}

Correspondence: Kalliopi Artemis Voudouri (kavoudou@auth.gr)

Received: 4 October 2018 - Discussion started: 5 December 2018

Revised: 12 July 2019 - Accepted: 15 July 2019 - Published: 29 August 2019

\begin{abstract}
In this study we apply and compare two algorithms for the automated aerosol-type characterization of the aerosol layers derived from Raman lidar measurements over the EARLINET station of Thessaloniki, Greece. Both automated aerosol-type characterization methods base their typing on lidar-derived aerosol-intensive properties. The methodologies are briefly described and their application to three distinct cases is demonstrated and evaluated. Then the two classification schemes were applied in the automatic mode to a more extensive dataset. The dataset analyzed corresponds to ACTRIS/EARLINET (European Aerosol Research Lidar NETwork) Thessaloniki data acquired during the period 2012-2015. Seventy-one layers out of 110 (percentage of $65 \%$ ) were typed by both techniques, and 56 of these 71 layers (percentage of $79 \%$ ) were attributed to the same aerosol type. However, as shown, the identification rate of both typing algorithms can be changed regarding the selection of appropriate threshold criteria. Four major types of aerosols are considered in this study: Dust, Maritime, PollutedSmoke and CleanContinental. The analysis showed that the two algorithms, when applied to real atmospheric conditions, provide typing results that are in good agreement regarding the automatic characterization of PollutedSmoke, while there are some differences between the two methods regarding the characterization of Dust and CleanContinental. These disagreements are mainly attributed to differences in the definitions of the aerosol types between the two methods, regarding the intensive properties used and their range.
\end{abstract}

\section{Introduction}

Aerosol classification is a key parameter in understanding the impact of different aerosol sources on climate, weather systems, and air quality. Given that aerosols are emitted from various sources, a significant number of aerosol types with different optical and microphysical properties coexist in the atmosphere. As a consequence, considerable uncertainties have been raised in the quantification of aerosols in the radiative transfer calculations and their interactions with clouds, leading the interest of wide communities in improving common understanding related to aerosol types and sources.

Nowadays, aerosol typing is an interesting topic recognized at international level, as inferring the aerosol source is an important tool for identification of events, alerting of dangerous situations, and definition of mitigation strategies. The International Satellite Aerosol Science Network (AEROSAT), for example, is an initiative established from different research groups around the world focusing on satellite aerosol retrieval. AEROSAT identifies the need for a common background for aerosol typing and typing procedure comparison efforts as one of the main important tasks to be tackled in the aerosol community (Mona et al., 2015).

Thus, a number of typing schemes have been applied to classify aerosols, based on the synergistic information of the backscattering and extinction coefficients and the polarization state of the received light at different wavelengths (e.g., Ansmann and Müller, 2005; Groß et al., 2013). For example, Hamill et al. (2016) developed an aerosol classification scheme using the optical properties derived from the 
AERONET (Aerosol Robotic Network) ground-based network of sun photometers. Five types of aerosols were defined based on reference clusters, characteristic of a particular type of aerosol (i.e., Maritime, Urban Industrial, Dust, Mixed and Biomass Burning). Schmeisser et al. (2017) also used aerosol optical properties (i.e., scattering Ångström exponent, absorption Ångström exponent and single scattering albedo) derived from in situ measurements in order to classify aerosols. Their typing scheme was based on three different aerosol classification methods.

Active remote sensing instruments such as ground- or space-based lidars are a key technique for characterizing aerosols as they can provide vertically resolved information on extensive (e.g., aerosol backscatter coefficient, aerosol extinction coefficient and volume depolarization ratio) and intensive properties (e.g., Ångström exponent, lidar ratio and particle depolarization ratio) of different aerosol types. The extensive properties depend on the aerosol concentration, whilst intensive ones are type-sensitive and provide separate classification for each detected layer (e.g., Müller et al., 2007; Ansmann et al., 2011; Tesche et al., 2011; Burton et al., 2012; Pappalardo et al., 2013; Groß et al., 2013; Amiridis et al., 2015; Giannakaki et al., 2015; Baars et al., 2016). Nevertheless, even intensive properties might not be sufficient to guarantee accurate typing, as some aerosol types (e.g., biomass burning and industrial pollution) have very similar intensive properties but are attributed to different sources and generating mechanisms. Indeed, volcanic and desert dust particles are both characterized by the asphericity of the particles, observable and measured through the linear depolarization ratio (while typically the other aerosol types have small values of this parameter), and their intensive optical properties could also be similar in ranges, e.g., Ångström exponents and lidar ratio (see, for example, Fig. 5 in Nicolae et al., 2018, Fig. 7 in Papagiannopoulos et al., 2018, and the variety of volcanic values in Mona et al., 2012).

Aerosol typing schemes have been developed for highresolution lidar measurements of space-borne lidars (e.g., CALIPSO, Cloud-Aerosol Lidar and Infrared Pathfinder Satellite Observation, Omar et al. 2009; EarthCARE, Illingworth et al., 2015; CATS, Yorks et al., 2016), airborne High Spectral Resolution Lidar - HSRL - measurements (e.g., Burton et al., 2012; Groß et al., 2013) and multiwavelength Raman measurements (e.g., Nicolae et al., 2018; Papagiannopoulos et al., 2018). The CALIPSO mission uses a decision tree based on lidar profiles and external data (Omar et al., 2009) in order to classify the aerosol load in 10 aerosol subtypes, i.e., marine, dust, polluted continental/smoke, clean continental, polluted dust, elevated smoke, dusty marine, PSC aerosol, volcanic ash, and sulfate/other. The upcoming mission of EarthCARE will depend on the high-spectral-resolution lidar products for aerosol classification. The aerosol-intensive properties at $355 \mathrm{~nm}$ combined with observations of the $355 \mathrm{~nm}$ aerosol optical depth will constitute the basic input for the aerosol-type determination
(Wandinger et al., 2016). An aerosol classification scheme from HSRL aerosol measurements has been introduced by Burton et al. (2012). Their technique applies an objective multivariate analysis using lidar-intensive properties (i.e., the particle linear depolarization ratio at $532 \mathrm{~nm}$, the particle lidar ratio at $532 \mathrm{~nm}$, the backscatter-related $532 / 1064 \mathrm{~nm}$ color ratio, and the ratio of particle linear depolarization ratios at 1064 and $532 \mathrm{~nm}$ ) and is able to discriminate eight aerosol types: smoke, fresh smoke, urban, polluted maritime, maritime, dusty mix, pure dust and ice.

Several other approaches have been developed based on the information provided by multispectral data of groundbased measurements. EARLINET, for example, is a wellstructured network of advanced laser remote sensing stations with the main purpose of understanding the horizontal and vertical distributions of aerosols on the European scale. The EARLINET data have been extensively used not only for climatological studies (e.g., Matthias et al., 2002; Mattis et al., 2004; Amiridis et al., 2005), but also for studies on Saharan dust outbreaks (e.g., Ansmann et al., 2003; Balis et al., 2004; Papayannis et al., 2008; Tesche et al., 2009b; Mona et al., 2014; Binietoglou et al., 2015), volcanic eruptions (e.g., Pappalardo et al., 2004; Sawamura et al., 2012; Pappalardo et al., 2013) and biomass-burning events (e.g., Balis et al., 2003; Tesche et al., 2011; Nicolae et al., 2013).

Efforts for detailed knowledge of the aerosol sources have been conducted in the framework of EARLINET, focusing on the aerosol characterization and typing. For example, Müller et al. (2007) presented for the first time a statistical analysis of lidar ratios for almost all climatically relevant aerosol types based solely on Raman lidar measurements. The analysis covered the most important aerosol types such as maritime particles, desert dust particles and aged biomassburning smoke. Lidar depolarization measurements have also been used to differentiate between different types of aerosols, since they constitute an indicator of the sphericity of particles. Tesche et al. (2009a) separate the optical properties of desert dust and biomass-burning particles using multiwavelength Raman and depolarization measurements. Methods for fine- and coarse-mode separation for dust outbreak cases, using the $532 \mathrm{~nm}$ particle depolarization ratio, have also been developed (e.g., Mamouri and Ansmann, 2014). Additionally, combined measurements of the lidar ratio from groundbased Raman lidars along with aerosol depolarization values and the size-sensitive Ångström exponent were proven to be a useful tool for the separation of aerosol types as shown by Groß et al. (2011). Furthermore, the combined use of lidar observations and transport model simulations permits the discrimination of desert dust and volcanic ash particles that typically have the same optical characteristics. Simultaneous observations of desert dust and ash particles were made during the Eyjafjallajökull volcanic eruption in 2010, and the methodology for the type discrimination was presented by Papayannis et al. (2012), Mona et al. (2012) and Pappalardo et al. (2013). 
Automated aerosol typing schemes have been discussed to be implemented in the next version of the EARLINET Single Calculus Chain tool (SCC; D'Amico et al., 2015). SCC was developed for the analysis of the data of different lidar systems in an automated, unsupervised way, and currently SCCv5.0.11 delivers profiles of optical aerosol properties. Future work is dedicated to the implementation of new features like profiles of intensive optical properties, detection of aerosol-layer geometrical properties and calculation of the intensive optical properties per detected layer, which will further allow the classification of the observed layers into aerosol types. Therefore, the need to define a common background on aerosol types (even the nomenclature is not harmonized nowadays) and compare aerosol types (which is not a numerical value) derived by different methods is at the top of interest and the following questions have been raised.

- Is there a common understanding for the aerosol types between different typing schemes?

- Can automated methods provide operationally accurate typing in automatic mode when applied to data stored in a climatological database?

- How can we compare different typing methodologies? Which parameters affect the agreement or disagreement between them and the ability to provide typing results?

Given the aforementioned status, a first attempt at comparing and evaluating two classification tools developed within EARLINET, which provide near-real-time aerosol typing information for the lidar profiles of Thessaloniki, is presented. Our aim is (i) to check the performance of both supervised learning techniques in their low-resolution mode, which is the case for the majority of the available measurements within EARLINET, when applied to lidar data from a station where, typically, variable mixtures of aerosols are present, and (ii) to investigate the reasons for typing agreement and disagreement with respect to the uncertainties and the threshold criteria applied. This paper can be considered a step towards the general objective of finding translating rules and a way to quantify differences between typing procedures.

The article is structured as follows: the Thessaloniki EARLINET lidar station is presented in Sect. 2. The two automatic aerosol classification methods and the methodology used to characterize the layers in four basic aerosol types (i.e., Dust, PollutedSmoke, Maritime, and CleanContinental) are presented in Sect. 3. In Sect. 4 the accuracy of the algorithms is tested by comparison with pre-classified case studies, the evaluation for the whole period under study is presented and the results of the study are discussed. Finally, Sect. 5 contains the summary and the conclusions of this article.

\section{Lidar system and measurement site}

The Thessaloniki lidar system (THELISYS) is operated and maintained by the Laboratory of Atmospheric Physics that is located in the Physics Department of the Aristotle University of Thessaloniki $\left(40.5^{\circ} \mathrm{N}, 22.9^{\circ} \mathrm{E} ; 50 \mathrm{~m}\right)$. THELISYS has been used for the detection of aerosol particles as a part of EARLINET (Bosenberg et al., 2003; Pappalardo et al., 2014) since 2000 and now is part of the Aerosols, Clouds, and Trace gases Research InfraStructure (ACTRIS; https: //www.actris.eu/, last access: 20 August 2019). Systematic measurements are performed following EARLINET's schedule (i.e., every Monday morning, and every Monday and Thursday evening after sunset). Additional measurements are performed during Saharan dust outbreaks, smoke advection from biomass burning, volcano eruption, and CALIPSO correlative measurements. The current setup of THELISYS includes three elastic backscatter channels at 355, 532 and $1064 \mathrm{~nm}$, two nitrogen Raman channels at 387 and $607 \mathrm{~nm}$, and two depolarization channels. These two channels have been added to measure the cross and parallel polarized signal at $532 \mathrm{~nm}$, but due to technical issues the particle depolarization ratio is available after August 2018. A detailed description of THELISYS can be found in Siomos et al. (2018a) and Siomos (2018). Data from THELISYS are regularly analyzed and quality assured and are publicly available at https://www.earlinet.org/ (last access: 20 August 2019).

Thessaloniki is in a location where many different types of aerosols coexist (Amiridis et al., 2009; Giannakaki et al., 2010; Siomos et al., 2018a). Dust events are dominant during summer above $1.5 \mathrm{~km}$ and in autumn below $1.5 \mathrm{~km}$, as shown by Siomos et al. (2018a). Marinou et al. (2017), also, used CALIPSO data and confirmed the existence of dust plumes during advection episodes over $2 \mathrm{~km}$ in summer. Similarly, the most intense biomass-burning episodes tend to occur during summer in the free troposphere and are probably associated with wildfires rather than agricultural fires that tend to be predominant during spring and autumn (Siomos et al., 2018a). Continental layers observed over Thessaloniki station are attributed to mixtures of anthropogenic pollution and particles from natural sources and even mixtures of maritime aerosol. Therefore, Thessaloniki is well suited for aerosol typing studies and for the investigation of the performances of different aerosol typing algorithms.

\section{Aerosol typing methods}

The two automatic aerosol typing methods require only lidar data with $3 \beta+2 \alpha$ configuration (three backscatter and two extinction coefficient profiles) without any use of ancillary external information. Specifically, the typing methods make use of the available aerosol-type-sensitive intensive properties. As multiwavelength Raman lidars have the ability to measure directly aerosol extinction and aerosol backscatter 
coefficient profiles in several wavelengths, a number of intensive properties can be acquired with high accuracy. A number of the obtained quantities do not depend on the aerosol load, but they can be linked to the size, the chemical composition, and/or the asphericity of the particles. The investigation of these quantities is important to infer the aerosol type, as discussed in many papers (e.g., Burton et al., 2012; Groß et al., 2013; Wandinger et al, 2016). In general, the ability for a successful classification of the different aerosol types and mixtures depends on the measurements uncertainties. As large measurement uncertainties prevent a correct aerosoltype separation, high-quality measurements are mandatory. The EARLINET lidar data follow the quality standards that have been established, in order to make the lidar products of the different systems comparable and to be able to provide quality-assured datasets of network products (Freudenthaler et al., 2018). So, the lidar dataset used in this study can be considered for typing characterization.

The intensive properties relevant to this study are the extinction-related Ångström exponent (AE), the backscatterrelated Ångström exponent (BAE), the ratio of the backscatter coefficients profiles (color ratios - CRs), the lidar ratio (LR), and the ratio of the lidar ratios (RLR). The respective formulas are provided in the following equations, where $\lambda$ is the wavelength, $z$ is the height, $a$ is the aerosol extinction coefficient, and $b$ is the aerosol backscatter coefficient.

$$
\begin{aligned}
& \operatorname{AE}_{\lambda 1 / \lambda 2}(z)=-\frac{\ln \left(\frac{a\left(\lambda_{1}, z\right)}{a\left(\lambda_{2}, z\right)}\right)}{\ln \left(\frac{\lambda_{1}}{\lambda_{2}}\right)} \\
& \operatorname{BAE}_{\lambda 1 / \lambda 2}(z)=-\frac{\ln \left(\frac{b\left(\lambda_{1}, z\right)}{b\left(\lambda_{2}, z\right)}\right)}{\ln \left(\frac{\lambda_{1}}{\lambda_{2}}\right)} \\
& \operatorname{CR}_{\lambda 1 / \lambda 2}(z)=\frac{b\left(\lambda_{1}, z\right)}{b\left(\lambda_{2}, z\right)} \\
& \operatorname{LR}\left(\lambda_{1}, z\right)=\frac{a\left(\lambda_{1}, z\right)}{b\left(\lambda_{1}, z\right)} \\
& \operatorname{RLR}_{\lambda 2 / \lambda 1}(z)=\frac{\operatorname{LR}\left(\lambda_{2}, z\right)}{\operatorname{LR}\left(\lambda_{1}, z\right)}
\end{aligned}
$$

The aerosol backscatter coefficients at two wavelengths $\left(\lambda_{1}<\lambda_{2}\right)$ are combined to give a backscatter-related aerosol Ångström exponent - $\operatorname{BAE}\left(\lambda_{1} / \lambda_{2}\right)$. This quantity provides information about the aerosol size and, in contrast to the extinction coefficient, is associated with smaller uncertainty. This is attributed mainly to the derivative in the inversion algorithm (e.g., Ansmann et al., 2002; Freudenthaler et al., 2009), which produces larger uncertainties, while the backscatter coefficient calculated from the combination of Raman elastic channels is less sensitive. The ratio of the aerosol extinction to backscatter coefficient is called the lidar ratio $-\mathrm{LR} \lambda_{1}$ - and changes largely for aerosols with different chemical and physical properties. This quantity has been valuable for aerosol characterization, as demonstrated in pre- vious studies (Müller et al., 2005; Mattis et al., 2004). The ratio of the lidar ratios $-\operatorname{LR} \lambda_{2} / \operatorname{LR} \lambda_{1}-$ can be used to assess the spectral dependency of the different aerosol types.

It is worthwhile mentioning that the particle linear depolarization ratio is an intensive property that effectively discriminates spherical and non-spherical particles in the atmosphere. Nevertheless, the particle depolarization can be very sensitive to the calibration procedure, and the values of the calculated particle depolarization also introduce a significant uncertainty. Given that this quantity is not used in the aerosol typing presented here, this study assesses aerosol typing capabilities for $3 \beta+2 \alpha$ lidars that do not make depolarization measurements.

\subsection{Neural network Aerosol Typing Algorithm based on Lidar data - NATALI}

The NATALI (Neural network Aerosol Typing Algorithm based on Lidar data) software relies on artificial neural networks (Nicolae et al., 2018). The development of this tool started in the framework of EARLINET, with the main purpose of identifying the most probable aerosol type using a combination of mean-layer-intensive optical parameters (i.e., lidar ratios, Ångström exponent, color ratios) from the provided aerosol backscatter and extinction coefficient profiles of lidar systems, without any additional information. The NATALI software consists of three independent, but interconnected modules: the input, the typing and the output module. The input module requires optical properties profiles as those measured by EARLINET stations, namely the aerosol extinction coefficient and the aerosol backscatter coefficient profile. Optionally, the linear particle depolarization profile at $532 \mathrm{~nm}$ can be provided, so as to allow a better classification and to increase the number of classified aerosol types.

In a first step, the typing module identifies the geometrical boundaries of the layers by applying the gradient method to the $1064 \mathrm{~nm}$ backscatter coefficient profile (Belegante et al., 2014). For every detected layer from the input module, calculations of the mean layer values of the intensive optical parameters and the associated uncertainties are performed (Nicolae et al., 2016). The extinction-related Ångström exponent at 355 and $532 \mathrm{~nm}\left(\mathrm{AE}_{355 / 532}\right)$, the backscatter-related Ångström exponent at 355 and $532 \mathrm{~nm}\left(\mathrm{BAE}_{355 / 532}\right)$, the backscatter-related Ångström exponent at 532 and $1064 \mathrm{~nm}$

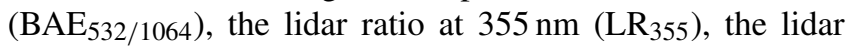
ratio at $532\left(\mathrm{LR}_{532}\right)$, and the ratio of the backscatter coefficients profiles (color ratios) $\mathrm{CR}_{355 / 532}$ and $\mathrm{CR}_{532 / 1064}$, are calculated. The acceptable ranges for the calculated intensive optical parameters should be between acceptable limits (i.e., extinction-related Ångström exponent values, backscatterrelated Ångström exponent values and color ratio values between -2 and 6 and lidar ratio values between 5 and 200), so as the quality of the input data to be ensured.

In a second step three artificial neural networks (ANNs) are interrogated simultaneously regarding the aerosol type 
using the aforementioned optical properties calculated for each layer. The ANNs have been trained using synthetic data from a specially designed aerosol model. Specifically, the synthetic database was developed using the aerosol model built for 350, 550, and $1000 \mathrm{~nm}$ sounding wavelengths, based on the 61 wavelengths of the OPAC (Optical Properties of Aerosols and Clouds) software package (Hess et al., 1998), for which the microphysical characteristics of the aerosols are available from the Global Aerosol Data Set (GADS). These wavelengths are then re-scaled to the usual lidar wavelengths (i.e., 355, 532 and $1064 \mathrm{~nm}$ ) using an average Ångström exponent equal to 1 . This was considered a valid assumption for all aerosol types, taking into account the small difference between the lidar and the model wavelengths. A comprehensive description of the developed aerosol model can be found in Nicolae et al. (2018).

The identification of the most probable aerosol type is then made through a voting procedure, using the results from the three ANNs interrogated. Over 50000 aerosol synthetic data have been used to train the ANN and identify the better ANNs to classify the aerosols type from multiwavelength lidar data. The capability of ANNs to resolve the overlapping clusters of the intensive optical parameters is used on the NATALI algorithm. The answer is selected based on a statistical approach. The selected types of ANNs classify the aerosols based on the response with high (i) confidence (i.e., the probability of having one of the aerosol types) and (ii) stability over the uncertainty range (i.e., the percentage of agreement for values between error limits). Therefore, answers with low confidence are filtered out and NATALI returns the "Unknown" type. These threshold criteria are selected by the user and are expressed as percentages. Higher values of these criteria, enhance the confidence of the classification and affect the identification rate of the typed cases. In our study, we test their application and we define the confidence level for the output retrievals higher than $90 \%$ (minimum accepted confidence) and the minimum agreement threshold as default (i.e., $25 \%$ ), in order to check the performance of NATALI in the highest confidence level.

Depending on the availability of the particle linear depolarization ratio and the quality of the provided lidar profiles, the derived typing can be either of high resolution $(\mathrm{AH})$, or low resolution with depolarization (AL), or low resolution without depolarization (BL). Pure aerosols categories, and even mixtures of three aerosols types can be obtained from the NATALI algorithm. In the high-resolution typing, 14 aerosol types can be distinguished (i.e., Continental, ContinentalPolluted, Dust, Maritime/CC, Smoke, Volcanic, Coastal, CoastalPolluted, ContinentalDust, ContinentalSmoke, DustPolluted, MaritimeMineral, MixedDust and MixedSmoke) when the quality of the provided optical products is high enough. In the low-resolution typing (AL), six predominant aerosol types can be provided but with high uncertainty (i.e., Continental, ContinentalPolluted, Smoke, Dust, Maritime and Volcanic). The low-resolution typing
(BL) provides five predominant aerosol types (i.e., Dust, ContinentalPolluted, Smoke, Continental, and Maritime), either pure or mixed, when the depolarization information is not provided. Finally, the output module provides the intensive optical parameters within each layer along with their mean value and the corresponding uncertainty. The complete and detailed typing procedure derived by NATALI can be found at Nicolae et al. $(2016,2018)$.

Application of NATALI to EARLINET data samples was also conducted. Observational data from the EARLINETCALIPSO database and measurements derived by a Raman depolarization lidar from the Romanian National Institute for Research and Development in Optoelectronics (Belegante et al., 2011) were used. The comparison between the NATALI aerosol typing module and these observational data showed consistent results (Nicolae et al., 2018). This comparison on EARLINET data samples showed the capability of NATALI to retrieve the aerosol type from an extensive dataset, with variable quality and physical content.

\subsection{EARLINET Mahalanobis distance-based typing algorithm - EMD}

The EARLINET Mahalanobis distance-based typing algorithm is a method specifically developed for the use on the EARLINET database with a high level of flexibility in order to adapt to the different lidar setups and needs (Papagiannopoulos et al., 2018). The algorithm applies the Mahalanobis distance classifier (Mahalanobis, 1936) to classify observations into a maximum of eight (Dust, Volcanic, MixedDust, PollutedDust, CleanContinental, MixedMarine, PollutedContinental, Smoke) and a minimum of four (Dust, Maritime, PollutedSmoke, CleanContinental) aerosol classes, considering the needs of each user and the provided number of the intensive properties. The method demonstrated to be high performing on aerosol typing using optical properties measurements in previous studies (e.g., Burton et al., 2012; Russell et al., 2014; Hamill et al., 2016).

The classification of each aerosol layer is made by calculating the distance of an observation from the predefined reference classes and by attributing each observation to a specific class based on the minimum distance. Given that the overall predictive accuracy of a typing algorithm depends on the predefined reference classes, the choice of the appropriate reference dataset is a crucial parameter. So, a wellcharacterized EARLINET dataset of observations from 2008 to 2010 was used to define the aerosol classes (Pappalardo et al., 2013; Papagiannopoulos et al., 2016; and Schwarz, 2016). As this dataset did not include all the typical aerosol components presented over Europe (i.e., Continental, Marine, Mineral dust and dust mixtures, Smoke, Volcanic ash), the observations were enhanced with additional ones (already published in the literature), contributing to a total of 69 layers (Pappalardo et al., 2013; Papagiannopoulos et al., 2016). 
In a next step, a sensitivity analysis was performed in order to identify the classifying properties that provide the most adequate information to better predict the correct aerosol class. The intensive properties that held the most weight among others in the classification were the backscatter-related Ångström exponent at 355 and $1064 \mathrm{~nm}$

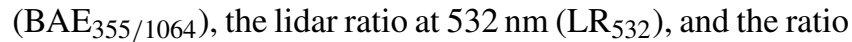
of the lidar ratios $\left(\mathrm{LR}_{532} / \mathrm{LR}_{355}\right)$.

Consequently, the initial reference dataset was split into a training and a validation dataset, in order to evaluate the predictive accuracy of the automatic method. Therefore, the training dataset was used to calculate the classification functions and then each observation was validated using the training dataset. Additionally, the effect of the depolarization information to the training phase was also investigated. To complement the reference dataset in this context, general literature values for particle linear depolarization ratio at $532 \mathrm{~nm}$ were used. Generally, the depolarization ratio is a really important parameter that can strengthen the typing procedure in the presence of aspherical layers, but Papagiannopoulos et al. (2018) showed that for the five (Dust, Maritime, PollutedContinental, Smoke, CleanContinental) and four (Dust, Maritime, PollutedSmoke, CleanContinental) classes, the particle linear depolarization ratio became less important (in this case the highest weight in the classification corresponds to the lidar ratio at $532 \mathrm{~nm}$ ).

Finally, the assessment of the predictive performance of the algorithm was tested on a testing dataset. For this purpose, EARLINET data collected during the ACTRIS Summer 2012 intensive measurements (Sicard et al., 2015; Granados-Muñoz et al., 2016) were chosen to test the automatic typing algorithm. The testing dataset comprised of 47 layers, 21 of which yielded depolarization ratio values. The performance of the algorithm was checked for each of the grouping classes (i.e., 8, 7, 6, 5, 4) and the predictive accuracy of the algorithm increased up to $90 \%$ when the aerosol classes that tend to reflect the same optical properties values were combined into 4 (Dust, Maritime, PollutedContinental + Smoke, CleanContinental) without providing the information of the depolarization. The study concluded that the fewer aerosol classes (i.e., 4, 5, and 6 classes) could provide a successful prediction accuracy, even without depolarization values, but, nonetheless, a coarser and less insightful classification. Dust classification showed a high success rate, whilst the aerosol types that performed worse were the smoke and polluted continental aerosol. However, when these two categories were combined into a single aerosol class, the correct prediction increased. More detailed description about the algorithm, the reference dataset and the set of the intensive parameters defined to separate different aerosol types can be found in Papagiannopoulos et al. (2018).

The outputs of the algorithm are (i) the calculated Mahalanobis distance of the layers from each aerosol class and (ii) the calculated chi-square probability. To improve the reliability of the output, two screening criteria are applied to the calculated distances following the procedure of Burton et al. (2012). The first one has to do with the minimum accepted distance which depends on the number of degrees of freedom (i.e., the type-dependent intensive properties) and the second one has to deal with the equal distances. In our study, we use the aforementioned three classifying parameters (i.e., the backscatter-related Ångström exponent at 355 and $1064 \mathrm{~nm}$ $\left(\mathrm{BAE}_{355 / 1064}\right)$, the lidar ratio at $532 \mathrm{~nm}\left(\mathrm{LR}_{532}\right)$, and the ratio of the lidar ratios $\left(\mathrm{LR}_{532} / \mathrm{LR}_{355}\right)$ ) and the minimum accepted distance for a measurement to be typed is 4 . When the distance is higher than the defined threshold, which means that no similarity with the aerosol classes of the reference datasets is found, the observation is not typed. So, the first filter ensures that the calculated distance has $99 \%$ probability (cumulative probability) to belong to the class that was estimated. If this happens for more than one classes, then the second filter is applied. According to this one, the normalized probability (the probability based on the calculated distances) of the aerosol class needs to be higher than $50 \%$ (Papagiannopoulos et al., 2018). Overall, the application of the two screening criteria enhances the confidence of the classification. However, the selection of a strict threshold (i.e., normalized probability greater than $60 \%$ ) enhances the correct prediction, but reduces the identification rate of the algorithm.

\subsection{Methodology}

Fifty-four (54) Raman lidar cases of aerosol measurements (backscatter coefficient profiles at 1064, 532 and $355 \mathrm{~nm}$, as well as the extinction coefficient profiles at 532 and $355 \mathrm{~nm}$ ) over Thessaloniki during the period 2012-2015 were used for this study. These input parameters were processed with NATALI algorithm for the identification of the layer boundaries, the calculation of their mean intensive optical parameters and their corresponding uncertainties. The NATALI typing was performed in the low-resolution typing configuration (five predominant aerosol types - Dust, Smoke, Continental Polluted, Continental and Maritime) since particle linear depolarization ratio measurements for Thessaloniki were not available for the study period.

In what follows, we merged the output types from NATALI that tend to reflect the same aerosol characteristics, and hence we evaluate the corresponding effects on the typing rate of the algorithms. Thus, the smoke and the polluted continental categories were grouped into the more generic type of small particles with high lidar ratio values (PollutedSmoke). The selection of four main aerosol classes stems from the availability of intensive properties, the difficulty in deriving a confident classification without particle linear depolarization ratio and the difficulty in discriminating polluted continental and smoke particles that reveal the same type characteristics. Regardless, the aerosol classes describe the major aerosol components. The identified layer boundaries from NATALI are used as input in the EARLINET Mahalanobis distance- 
Table 1. Nomenclature of the aerosol types used in the high- and low-resolution (without depolarization) modes for both automatic typing techniques and the correspondence with the ones used in this study.

\begin{tabular}{|c|c|c|c|c|}
\hline \multicolumn{2}{|c|}{ NATALI } & \multicolumn{2}{|c|}{ EARLINET Mahalanobis } & \multirow{2}{*}{$\begin{array}{l}\text { This study } \\
\text { Low resolution }\end{array}$} \\
\hline High resolution & Low resolution & High resolution & Low resolution & \\
\hline Continental & Continental & CleanContinental & Continental & CleanContinental \\
\hline $\begin{array}{l}\text { ContinentalPolluted, } \\
\text { ContinentalSmoke, Smoke, } \\
\text { MixedSmoke/CC }\end{array}$ & $\begin{array}{l}\text { Continental polluted, } \\
\text { Smoke, Continental } \\
\text { Smoke }\end{array}$ & $\begin{array}{l}\text { Polluted Continental, } \\
\text { Smoke }\end{array}$ & PollutedSmoke & PollutedSmoke \\
\hline $\begin{array}{l}\text { Dust, Volcanic, DustPolluted, } \\
\text { MixedDust/CC, Continental } \\
\text { Dust, Mineral Mixtures/Volcanic }\end{array}$ & Dust & $\begin{array}{l}\text { Dust, Volcanic, Mixed } \\
\text { Dust, Polluted Dust }\end{array}$ & Dust, Polluted Dust & Dust \\
\hline $\begin{array}{l}\text { Marine, CoastalPolluted/CC, } \\
\text { Coastal/CC }\end{array}$ & Marine & Mixed Marine & Mixed Marine & Maritime \\
\hline
\end{tabular}

Table 2. Mean aerosol optical properties of the reference aerosol types used on the two automated algorithms.

\begin{tabular}{lrrrrr}
\hline NATALI & $\mathrm{AE}_{350 / 550}$ & $\mathrm{LR}_{350}$ & $\mathrm{LR}_{550}$ & $\mathrm{CR}_{350 / 550}$ & $\mathrm{CR}_{550 / 1000}$ \\
\hline Dust (D) & $0.88-0.92$ & $43-46$ & $44-49$ & $1.51-1.55$ & $1.1-1.14$ \\
ContinentalPolluted (CPolluted) & $1.17-1.34$ & $55-75$ & $62-74$ & $1.34-2.29$ & $1.33-1.65$ \\
Smoke (S) & $1.15-1.31$ & $56-72$ & $81-92$ & $1.90-2.59$ & $1.52-1.61$ \\
Continental (CC) & $1.17-1.29$ & $43-54$ & $52-53$ & $1.56-2.07$ & $1.37-1.85$ \\
Maritime (M) & $-0.26-0.21$ & $13-32$ & $19-25$ & $0.77-1.35$ & $0.7-2.91$ \\
\hline EARLINET Mahalanobis distance-based typing algorithm & $\mathrm{BAE}_{355 / 1064}$ & $\mathrm{LR}_{532}$ & $\mathrm{LR}_{532} / \mathrm{LR}_{355}$ \\
\hline Dust (D) & & $0.01-1.0$ & $41-63$ & $0.77-1.04$ \\
PollutedSmoke (PS) & & $1.0-1.9$ & $50-97$ & $0.87-1.6$ \\
CleanContinental (CC) & & $0.7-1.6$ & $32-44$ & $0.62-1.04$ \\
Maritime (M) & & $0.5-1.2$ & $16-32$ & $0.81-0.9$ \\
\hline
\end{tabular}

based typing algorithm. Considering the aforementioned typing merging, the EARLINET Mahalanobis distance-based typing algorithm was set to classify observations into four aerosol classes: CleanContinental, Dust, Maritime and PollutedSmoke.

Table 1 lists the aerosol types used in the aerosol classification and their correspondence with the available types provided by the two typing methods and Table 2 lists the mean aerosol optical properties of the reference aerosol types defined by the two algorithms. The idea here is to compromise (i) the resolution (low) of the automatic classification owing to the availability of the optical properties (i.e., $3+2$ lidar configuration), and (ii) the type definition, which does include the wide spectrum of the aerosol types provided by the two automated typing techniques. As is evident from the values presented in Table 2, the lidar classification scheme consists of the main classes: (i) large particles with medium lidar ratios (i.e., dust-like particles), (ii) large particles with low lidar ratios (i.e., maritime particles), (iii) small particles with high lidar ratios (i.e., pollution and/or smoke particles) and (iv) small particles with medium lidar ratios (i.e., clean continental particles). Generally, desert dust layers have optical properties that are considerably different from the other types. Their big size leads to low Ångström exponent values and the reported lidar ratio at $355 \mathrm{~nm}$ ranges from 47 to $58 \mathrm{sr}$ for Thessaloniki (Siomos et al., 2018a). PollutedSmoke particles are highly absorbing particles, with high lidar ratio values. CleanContinental categorization is not completely straightforward, because the continental particles can be attributed to different subcategories (i.e., local, continental polluted or mixtures). In general, the CleanContinental cases are typically elevated layers, i.e., layers not related to the local atmospheric boundary layer where the pollution and anthropogenic contribution would mean more absorbing particles and therefore labeled as PollutedSmoke aerosol.

\section{Application of the two automatic algorithms to EARLINET data - case studies}

The application of the two automated aerosol typing algorithms to aerosol classification for three cases is presented and discussed in detail. A Saharan dust outbreak, a biomass- 


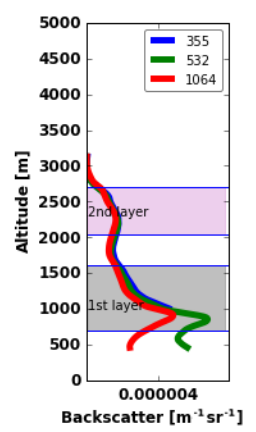

(a)

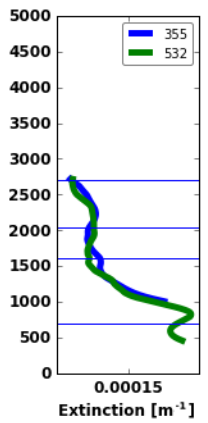

(b)

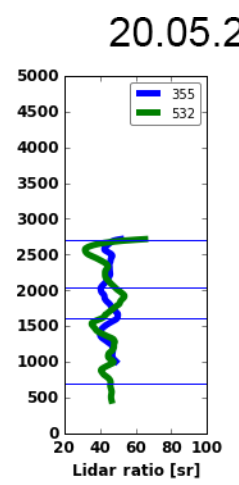

(c)

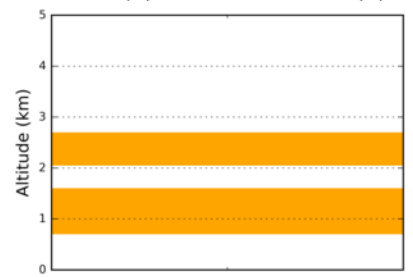

(f)

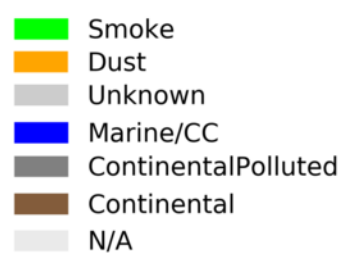

N/A

Figure 1. Vertical profiles of aerosol optical properties for Thessaloniki on 20 May 2013. (a) Backscatter coefficient at 355 , 532 and $1064 \mathrm{~nm}$, (b) extinction coefficient at 355 and $532 \mathrm{~nm}$, (c) lidar ratio, (d) Ångström exponent, (e) 4-day HYSPLIT backward trajectories arriving at Thessaloniki at each detected layer height, (f) aerosol main layers typed by NATALI and (g, h) EARLINET Mahalanobis distance-based typing algorithm probability for each detected layer (different from the normalized one).

burning case and a complex aerosol structure scene over Thessaloniki station are presented below. The typing results are compared against manually typed profiles that were characterized using satellite data and model simulations. Specifically, in order to identify the source of aerosol particles, backward trajectories are calculated using the Hybrid SingleParticle Lagrangian Integrated Trajectory model (HYSPLIT; Stein et al., 2015). Additionally, the BSC-DREAM8b model (e.g., Basart et al., 2012b) was used to verify the presence of Saharan dust. Finally, fire spots from the space-based MODIS sensor (https://firms.modaps.eosdis.nasa.gov/map/, last access: 20 August 2019) product FIRMS (Fire Information for Resource Management System; Giglio et al., 2016) were used to confirm the presence of smoke over Thessaloniki.

\subsection{Dust case}

The first case refers to the occurrence of a dust plume over the station of Thessaloniki on 20 May 2013. The retrieved profiles of the particle backscatter and extinction coefficient, lidar ratios, and Ångström exponents are shown in Fig. 1a$\mathrm{d}$. The measurement is characterized by two particle layers, the first one between 0.7 and $1.6 \mathrm{~km}$ and the second one between 2.0 and $2.7 \mathrm{~km}$. The dust presence was confirmed by the 4-day backward trajectories arriving at Thessaloniki on 20 May 2013 (Fig. 1e). The trajectories indicated an event of transported Saharan dust. Additionally, the BSC-DREAM8b model is used to verify the presence of Saharan dust. The aerosol main layers and NATALI typing results are presented in Fig. 1f. For each aerosol layer (i.e., Layer 1: 0.7-1.6 km; and Layer 2: 2-2.7 km), the mean optical properties are calculated using NATALI.

The lidar ratio values for Layer 1 are $45 \pm 3 \mathrm{sr}$ for $355 \mathrm{~nm}$ and $43 \pm 1.1 \mathrm{sr}$ for $532 \mathrm{~nm}$, and for Layer 2 they are $45 \pm 1.4 \mathrm{sr}$ for $355 \mathrm{~nm}$ and $41 \pm 1.3 \mathrm{sr}$ for $532 \mathrm{~nm}$ correspondingly.

The ratio of the lidar ratio values $\left(\mathrm{LR}_{532} / \mathrm{LR}_{355}\right)$ for Layer 1 is $0.94 \pm 0.083$, and for Layer 2 it is $0.92 \pm 0.13$.

The mean $\mathrm{AE}_{355 / 532}$ is $0.33 \pm 0.06$ for Layer 1 and $0.38 \pm$ 0.07 for Layer 2, respectively. The mean $\mathrm{BAE}_{355 / 532}$, mean $\mathrm{BAE}_{532 / 1064}$ and mean $\mathrm{BAE}_{355 / 1064}$ are $0.24 \pm 0.06,0.28 \pm$ 0.04 and $0.32 \pm 0.22$ for the first layer, while the values for Layer 2 are $0.13 \pm 0.07,0.06 \pm 0.04$ and $0.05 \pm 0.1$, respectively. The stability of the lidar ratio and Ångström exponent values could be considered an indicator of homogeneity and small variability of the aerosol type within the layer. The retrieved values indicate the presence of coarse particles and are in agreement with the typical dust values observed over Thessaloniki (Siomos et al., 2018a). Also, Müller et al. (2007) reported values of the mean backscatter-related Ångström exponent $\mathrm{BAE}_{355 / 1064}$ of $0.2 \pm 0.2$ for desert dust events. NATALI typing output indicates dust layers (Fig. 1f). The EARLINET Mahalanobis distance-based typing algorithm also classifies Layers 1 and 2 as dust cases (Mahalanobis distance is minimum), and Mahalanobis probability also shows good predictive performance $(68 \%$ for Layer 1 and $44.6 \%$ for Layer 2) (Fig. 1g-h). The plotted probabili- 
09.02.2013 Thessaloniki

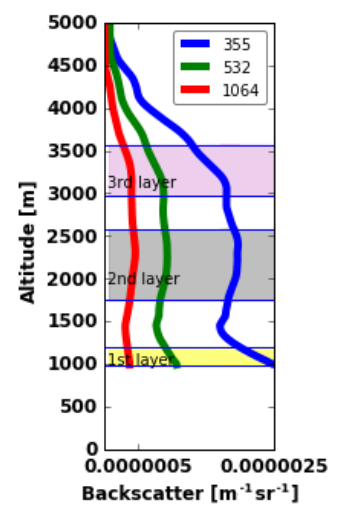

(a)

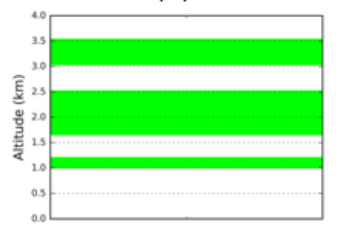

(f)

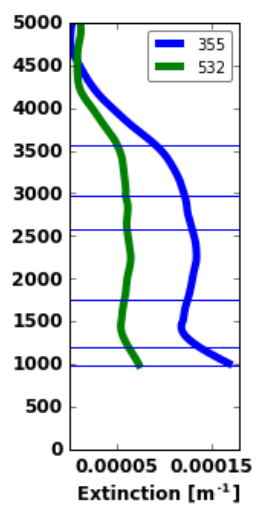

(b)

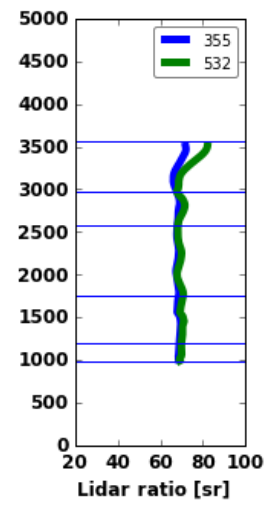

(c)

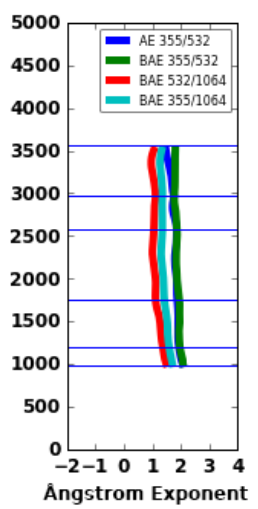

(d)

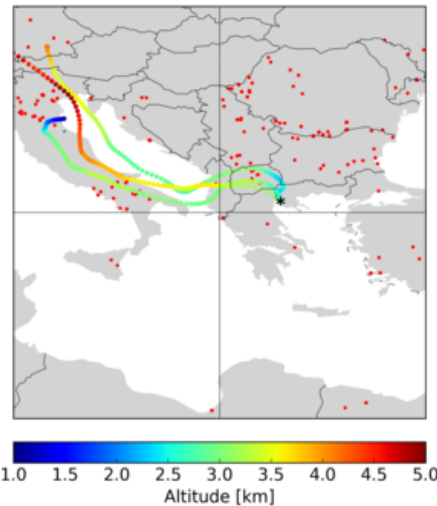

(e)

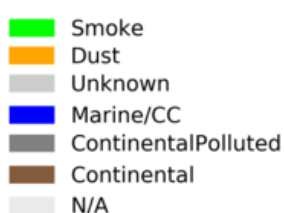

N/A

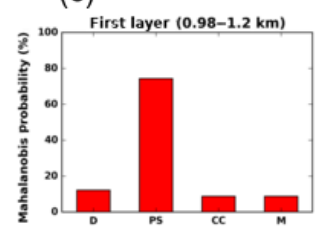

(g)

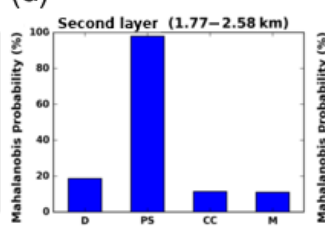

(h)

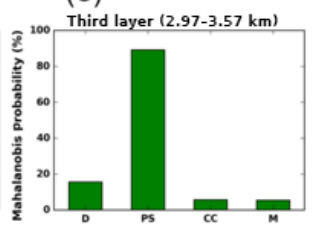

(i)

Figure 2. Vertical profiles of aerosol optical properties for Thessaloniki on 2 September 2013. (a) Backscatter coefficient profiles at 355 , 532 and $1064 \mathrm{~nm}$, (b) extinction coefficient profiles at 387 and $607 \mathrm{~nm}$, (c) lidar ratio, (d) Ångström exponent, (e) 3-day backward trajectories arriving at Thessaloniki at each detected layer height, (f) aerosol main layers typed by NATALI, and (g-i) EARLINET Mahalanobis distancebased typing algorithm probability for each detected layer (different from the normalized one).

ties are assigned to each calculated distance and are different from the normalized ones that are used as a screening criterion (and add up to 100).

\subsection{Biomass-burning case}

The second case is a biomass-burning episode that occurred on 2 September 2013. The 3-day backward trajectories from HYSPLIT in conjunction with fire spots from MODIS satellite product FIRMS indicate the biomass-burning episode, transported from central Europe in the region of Thessaloniki. The optical profiles and the layers of aerosols are shown in Fig. 2a-d.

The measurement is characterized by three particle layers: the first one is between 0.98 and $1.2 \mathrm{~km}$ (Layer 1), the second one between 1.7 and $2.6 \mathrm{~km}$ (Layer 2) and the third one between 2.9 and $3.5 \mathrm{~km}$ (Layer 3). The upper and lower boundaries of each layer are marked with lines. NATALI typing is presented in Fig. 2f.

The mean values of all optical parameters for each detected layer are calculated. The mean lidar ratio is calculated as $69 \pm 4$ for $355 \mathrm{~nm}$ and $70 \pm 4$ for $532 \mathrm{~nm}$ (Layer 1), for Layer 2 it is $68 \pm 2 \mathrm{sr}$ for $355 \mathrm{~nm}$ and $69 \pm 2 \mathrm{sr}$ for $532 \mathrm{~nm}$, and Layer 3 has values of $69 \pm 2.3 \mathrm{sr}$ for $355 \mathrm{~nm}$ and $75 \pm 2.5 \mathrm{sr}$ for $532 \mathrm{~nm}$.

The ratio of the lidar ratio values $\left(\mathrm{LR}_{532} / \mathrm{LR}_{355}\right)$ for Layer 1 is $1.02 \pm 0.004$, for Layer 2 it is $1.02 \pm 0.007$ and for Layer 3 it is $1.09 \pm 0.048$.
The mean Angström (AE) exponent for each layer is estimated at $1.99 \pm 0.13$ (Layer 1), $1.84 \pm 0.06$ (Layer 2) and $1.61 \pm 0.08$ (Layer 3 ). These values are consistent with previous reported ones; e.g., Baars et al. (2012) reported values of the extinction Ångström exponent for smoke of $1.17 \pm 0.44$.

The mean backscatter-related Ångström exponent (BAE) at $355-532 \mathrm{~nm}$ is $2.03 \pm 0.13$ (Layer 1), $1.88 \pm 0.06$ (Layer 2) and $1.80 \pm 0.08$ (Layer 3), while the mean backscatterrelated Ångström exponent (BAE) at 532-1064 nm is $1.43 \pm$ 0.07 (Layer 1), $1.08 \pm 0.04$ (Layer 2) and $1.03 \pm 0.05$ (Layer 3), and the mean backscatter-related Ångström exponent (BAE) at $355-1064 \mathrm{~nm}$ is $1.63 \pm 0.07$ (Layer 1), $1.36 \pm 0.04$ (Layer 2) and $1.31 \pm 0.03$ (Layer 3), respectively.

These values are in accordance with the typical biomassburning values observed over Thessaloniki. Giannakaki et al. (2010) reported an annual mean lidar ratio at $355 \mathrm{~nm}$ of $69 \pm 17 \mathrm{sr}$ and a mean BAE at $355-532 \mathrm{~nm}$ of $1.7 \pm 0.7$, while Siomos et al. (2018a) found a lidar ratio at $355 \mathrm{~nm}$ ranging from 51 to 73 sr for biomass-burning events. NATALI aerosol output (Fig. 2f) and the EARLINET Mahalanobis distancebased typing algorithm values (distance and probability) also confirm the presence of smoke layers (Fig. $2 \mathrm{~g}-\mathrm{k}$ ). The plotted probabilities are assigned to each calculated distance and are different from the normalized ones that are used as a screening criterion (and add up to 100). 


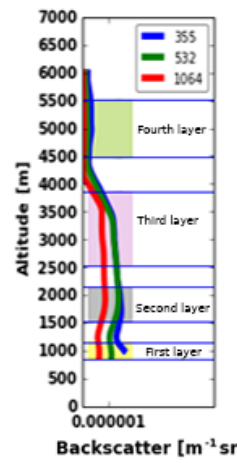

(a)

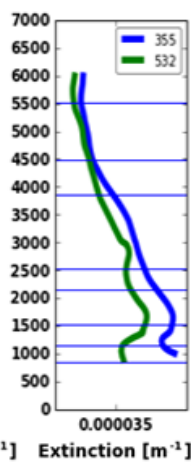

(b)

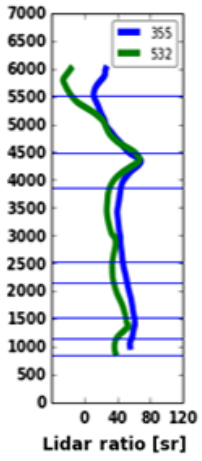

(c)

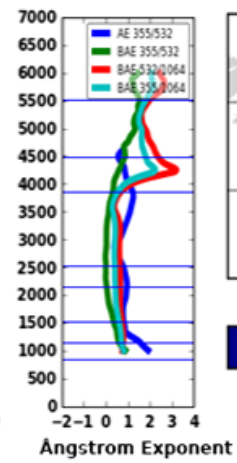

(d)

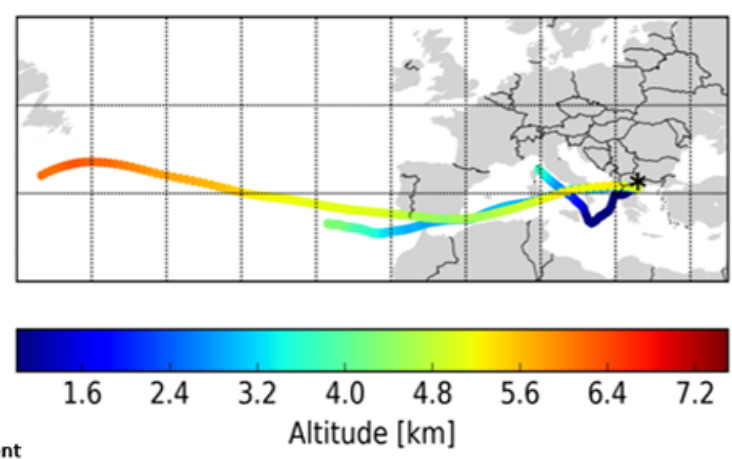

(e)

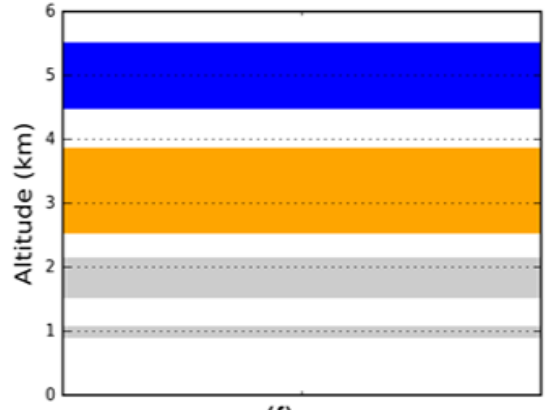

(f)

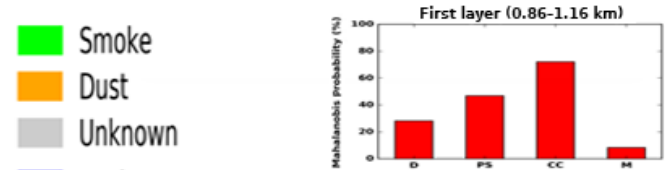

(g)

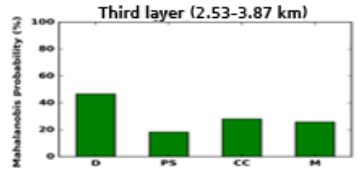

(i)

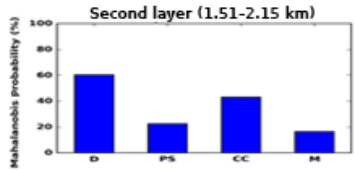

(h)

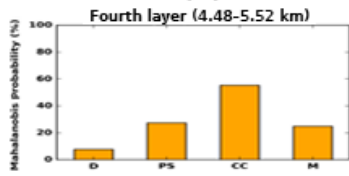

(j)

Figure 3. Vertical profiles of aerosol optical properties for Thessaloniki on 21 August 2014. (a) Backscatter coefficient profiles at 355, 532 and $1064 \mathrm{~nm}$, (b) extinction coefficient profiles at 387 and $607 \mathrm{~nm}$, (c) lidar ratio, (d) Ångström exponent, (e) 5-day backward trajectories arriving at Thessaloniki at each detected layer height, (f) aerosol main layers typed by NATALI, and (g-j) EARLINET Mahalanobis distancebased typing algorithm probability for each detected layer (different from the normalized one).

\subsection{Mixed case}

The third case is one with a complex aerosol structure that occurred on 21 August 2014. This case offers the opportunity to check the reliability of the algorithms in conditions where different aerosol types in different layers exist. The 5day backward simulation from HYSPLIT indicates the pattern of the origin of air masses before reaching the study area as presented in Fig. 3e. The motion of the particles is in a southwesterly direction from a dust source towards Thessaloniki. So, the path of the air masses arriving over Thessaloniki suggests a mixture of dust (at a height of about $3 \mathrm{~km}$ ) and continental and marine particles. The optical profiles and the layers of aerosols are shown in Fig. 3a-d.

The measurement is characterized by four particle layers: the first one is between 0.9 and $1.10 \mathrm{~km}$ (Layer 1), the second one between 1.5 and $2.1 \mathrm{~km}$ (Layer 2), the third one between 2.5 and $3.8 \mathrm{~km}$ (Layer 3) and the fourth one between 4.47 and $5.52 \mathrm{~km}$. The upper and lower boundaries of each layer are marked with lines. NATALI typing is presented in Fig. 3f. The mean values of all optical parameters for each detected layer are calculated.

The mean lidar ratio is calculated as $56 \pm 3.17$ for $355 \mathrm{~nm}$ and $37 \pm 2.09$ for $532 \mathrm{~nm}$ (Layer 1), for Layer 2 it is $57 \pm$
$1.75 \mathrm{sr}$ for $355 \mathrm{~nm}$ and $44 \pm 1.35 \mathrm{sr}$ for $532 \mathrm{~nm}$, Layer 3 has values of $43 \pm 0.91 \mathrm{sr}$ for $355 \mathrm{~nm}$ and $42 \pm 0.68 \mathrm{sr}$ for $532 \mathrm{~nm}$ and Layer 4 has values of $29 \pm 0.77 \mathrm{sr}$ for $355 \mathrm{~nm}$ and $30 \pm$ $0.91 \mathrm{sr}$ for $532 \mathrm{~nm}$.

The ratio of the lidar ratio values $\left(\mathrm{LR}_{532} / \mathrm{LR}_{355}\right)$ for Layer 1 is $0.66 \pm 0.08$, for Layer 2 it is $0.77 \pm 0.05$, for Layer 3 it is $0.97 \pm 0.067$ and for Layer 4 it is $1.03 \pm 0.1$.

The mean Angström exponent (AE) for each layer is estimated at $2 \pm 0.14$ (Layer 1), $0.86 \pm 0.08$ (Layer 2), $0.85 \pm 0.05$ (Layer 3) and $1.72 \pm 0.07$ (Layer 4).

The mean backscatter-related Ångström exponent (BAE) at $355-532 \mathrm{~nm}$ is $0.98 \pm 0.14$ (Layer 1), $0.19 \pm 0.08$ (Layer 2), $0.10 \pm 0.05$ (Layer 3) and 1.21 \pm 0.06 (Layer 4).

The mean backscatter-related Angström exponent (BAE) at $532-1064 \mathrm{~nm}$ is $0.77 \pm 0.08$ (Layer 1), $0.68 \pm 0.04$ (Layer 2), $0.58 \pm 0.03$ (Layer 3) and $1.9 \pm 0.03$ (Layer 4).

The mean backscatter-related Ångström exponent (BAE) at $355-1064 \mathrm{~nm}$ is $0.78 \pm 0.07$ (Layer 1), $0.49 \pm 0.04$ (Layer 2), $0.39 \pm 0.03$ (Layer 3) and $1.64 \pm 0.03$ (Layer 4), respectively. NATALI aerosol output is presented in Fig. 3f. NATALI classifies as Unknown Layer 1 and Layer 2, as the ANNs could not identify any aerosol type (no ANNs passed the threshold criteria), and classifies Layer 3 as Dust and Layer 4 as Maritime. The EARLINET Mahalanobis 
distance-based typing probability values are presented in Fig. $3 g-j$.

Layer 1 is classified as CleanContinental, Layer 2 and Layer 3 as Dust and Layer 4 as CleanContinental. Both typing techniques classify Layer 3 as Dust. The values of the optical parameter indicate the presence of coarse particles and are in agreement with the typical dust values observed over Thessaloniki (Siomos et al., 2018a). Layer 4 is typed differently. This layer is recognized by NATALI as a Maritime one (lower lidar ratio values), while in the EARLINET Mahalanobis distance-based typing method it is attributed as a signature for CleanContinental. Layer 1 and Layer 2 are typed as Unknown layers from NATALI. However, Layer 1 is recognized as CleanContinental by the EARLINET Mahalanobis distance-based typing method, with mean backscatter-related Ångström exponent and lidar ratio values representative of the continental particles allowed in the EARLINET Mahalanobis distance-based typing method (Table 2). Given that the two algorithms take into consideration different combinations of the intensive optical properties (i.e., NATALI uses AE), this is also a reason to differentiate the output retrieval. The layer high Ångström exponent of Layer 1, considered in the NATALI typing algorithm, maybe is the reason that ANNs answers are filtered out. As with Layer 2, NATALI returns the layer as Unknown, due to the low confidence level of the ANN outputs. However, the EARLINET Mahalanobis distance-based typing method classifies the layer as Dust, based on the values of the optical parameters used for typing (Table 2). This example demonstrates that type assignment is quite challenging and not always possible in ambiguous atmospheric scenes.

\subsection{Automated aerosol classification using NATALI and EARLINET Mahalanobis distance-based typing algorithm}

The complete Thessaloniki multiwavelength Raman lidar dataset for the 2012-2015 period is analyzed in terms of aerosol typing with NATALI and the EARLINET Mahalanobis distance-based typing algorithm using the automated methodologies reported in Sects. 3.1 and 3.2. For the 54 cases, 120 layers are identified by the layer identification module of NATALI, out of which 10 layers are rejected due to the fact that they were below $1 \mathrm{~km}$ (below overlap region).

NATALI classified 82 of the total 110 layers $(75 \%$ of the total number of cases) and 28 were flagged as Unknown layers. These missed cases are based mostly on retrievals with large uncertainties of the optical parameters and the calculated uncertainties and rely on the minimum acceptance confidence that prohibited ANNs from returning an aerosol-type classification. However, these "unknowns" layers provided type results $(93 \%)$ when the minimum acceptance confidence was set to $70 \%$. However, in this study we investigate the application of the NATALI algorithm, holding the retrievals that pass a higher percentage of quality checks. The
EARLINET Mahalanobis distance-based typing algorithm classified 98 layers (89\%) and 12 layers were not assigned to any cluster (the Mahalanobis distance values larger than 4), showing a higher identification rate. However, this rate also depends on the screening criteria. When we set the second of the screening criteria (i.e., the normalized probability of the aerosol class) to be higher than $50 \%$, the number of untyped layers increased (22 untyped cases, $80 \%$ typing rate). Overall, the identification rate can be changed regarding the needs of the user and the selection of the appropriate threshold criteria. In addition, we examined the ability of both methods to provide typing results relative to the derived layer optical depth (aerosol optical depth - AOD) values. This study showed that the mean layer AOD of the typed layers has a similar value for both typing techniques $(0.1076 \pm 0.0898$ (SD) for NATALI and $0.11166 \pm 0.0928$ (SD) for the EARLINET Mahalanobis distance typing algorithm). However, the EARLINET Mahalanobis distance algorithm seems more sensitive to lower values (untyped cases show a mean layer AOD of $0.0298 \pm 0.0578$ for the EARLINET Mahalanobis distance algorithm, in contrast to the $0.06899 \pm 0.0606$ for NATALI). These low AOD values are associated with higher uncertainties in the intensive properties.

Figure $4 \mathrm{a}$ and $\mathrm{c}$ present the percentages of the total typed layers into the defined aerosol classes for both automated algorithms. Also, the untyped layers from the EARLINET Mahalanobis distance-based typing algorithm that were typed by NATALI and visa versa are presented in Fig. $4 \mathrm{~b}$ and $d$. The EARLINET Mahalanobis distance-based typing algorithm classified 27 of the 28 untyped layers by NATALI as follows: 6 layers as Dust (21.4\%), 10 as PollutedSmoke (35.7\%), 10 as CleanContinental (35.7\%) and only 1 layer as Maritime $(3.6 \%)$. Here again, the EARLINET Mahalanobis distance-based typing algorithm indicated the PollutedSmoke and CleanContinental categories as the main sources of the aerosol layers observed, while the Maritime category is the less pronounced one. On the other hand, NATALI classified 11 of the 12 untyped layers from the EARLINET Mahalanobis distance-based typing algorithm as follows: 2 layers were typed as Dust $(16.7 \%), 6$ as PollutedSmoke $(50 \%)$ and 3 layers as Maritime $(25 \%)$. In general, NATALI software seems more sensitive to the Maritime category. In particular, the agreement is reasonably close for the desert dust cases $(10 \%$ and $17 \%$ for NATALI and the EARLINET Mahalanobis distance-based typing algorithm, respectively); nevertheless, it becomes evident that the particle linear depolarization ratio could increase the ability to correctly predict dust particles (Fig. 4). The agreement is remarkable for the PollutedSmoke cases, with occurrence ratios of $43 \%$ and $47 \%$ for NATALI and the EARLINET Mahalanobis distance-based typing algorithm, respectively, whilst the CleanContinental cases showed a difference with $18 \%$ and $24 \%$ for NATALI and the EARLINET Mahalanobis distance-based typing algorithm, respectively. Also, 
Aerosol typing by Mahalanobis

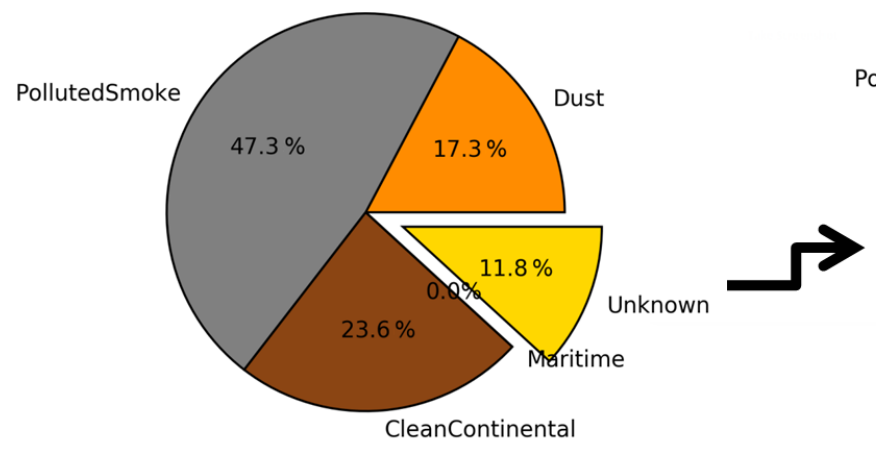

(a)

\section{U/N layers from NATALI typed by Mahalanobis}

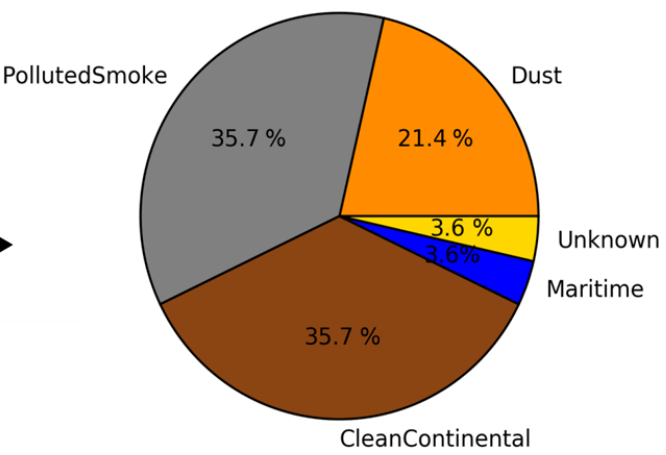

(b)

\section{Aerosol typing by NATALI}

\section{U/N layers from Mahalanobis typed by NATALI}

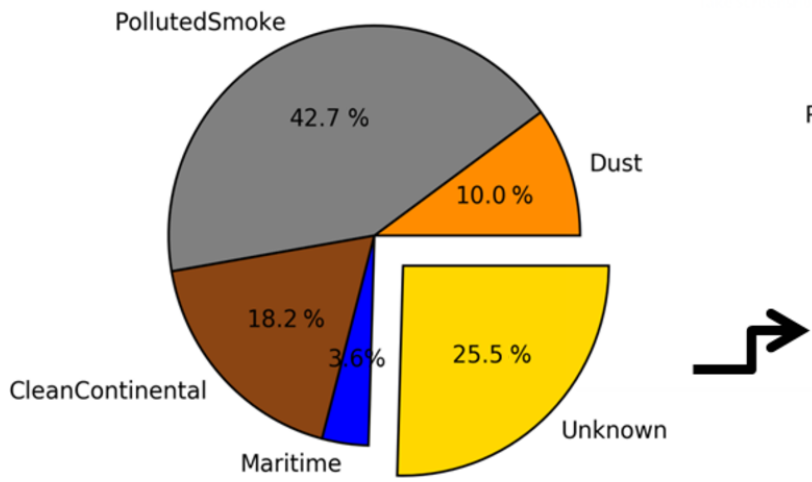

(c)

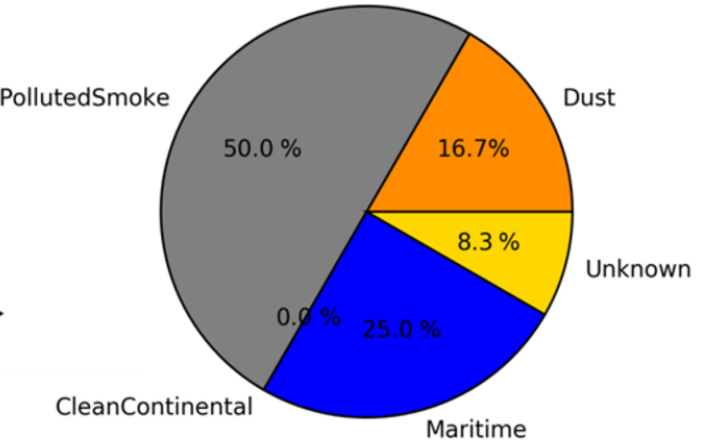

(d)

Figure 4. Percentages of typed and untyped layers for both automated algorithms.

difference is observed for the Maritime category, where one case is attributed to this category by NATALI.

The differences observed in Fig. 4, primarily, can be described by the different definitions of the aerosol classes for the two typing methods. It is worth noting that the aerosol model for the NATALI typing method was trained based on synthetic data. The comparison between the aerosol model values used for the training and the reported literature values showed differences (Nicolae et al., 2018) as follows: synthetic values found lower than those observed for continental-rural (AE 350/550), continental-polluted (CR 500/1000), and dust (CR 500/1000) types and synthetic values are greater for continental-rural (LR350) and volcanic (DEP 550) types. The reasons for these differences could be related on the one hand to uncertainty or variability issues of the measured values and on the other hand to the aerosol model limitations, e.g., due to spheroidal model and monomodal log-normal distribution (Nicolae et al., 2018). On the other hand, for the EARLINET Mahalanobis distance-based typing method the aerosol reference class is defined using an ensemble of high-quality EARLINET observations. However, different measurement locations may be a reason for mismatches in the attributed aerosol category. Moreover, the general different approaches of the two methods may have an impact on the aerosol typing even though both classifications schemes have been trained using supervised learning techniques. In addition to the ability of the two automated algorithms to attribute the correct type to the aerosol layers, the uncertainties of the input measurements also have to be taken into account. Both algorithms are unable to return aerosol type for not well-calibrated input data, i.e., when one or more intensive optical properties have large uncertainties.

In what follows, a comparison is made to the 71 common layers identified by both algorithms. Figure 5 presents the number of detected layers per typing class attributed by each algorithm for the whole study period. The two algorithms attributed the same aerosol type to 56 layers, showing an agreement of $78.8 \%$ of the typed cases. The typing procedures show the predominance of the PollutedSmoke category for Thessaloniki, followed by the CleanContinental category. 


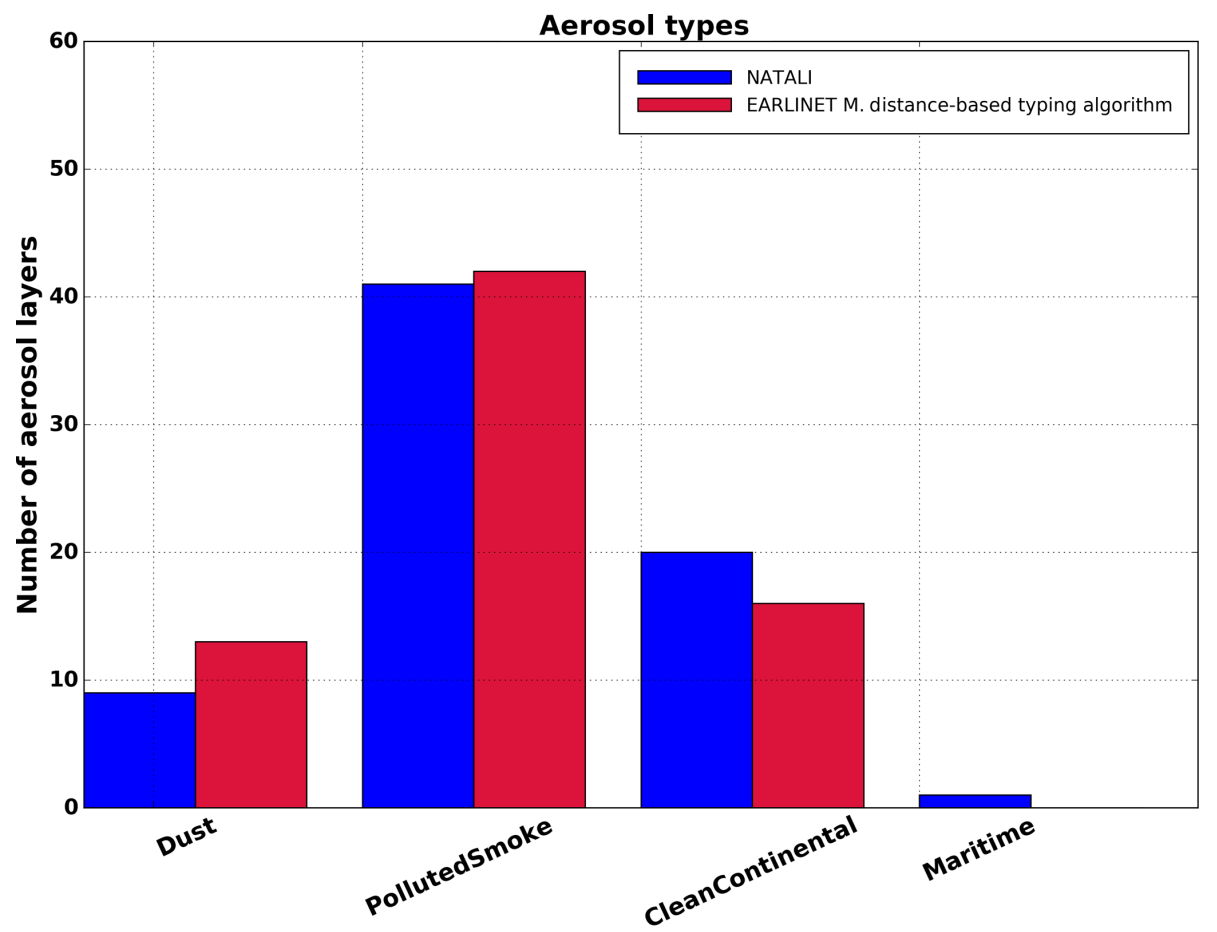

Figure 5. The number of detected layers from both algorithms, based on the 71 cases where both algorithms provided results.

This result is consistent with the CALIPSO scheme at global level and with results on Thessaloniki site characterization done by Siomos et al. (2018b). In their paper, Siomos et al. (2018b) used data from a double monochromator Brewer spectrophotometer and a sun photometer in order to classify aerosol cases during the period 2007-2017 in Thessaloniki: they found that the Water Soluble category (which can be related to the CleanContinental consisting of water-soluble particles) corresponded to $29.1 \%$ of the cases, which is in fair agreement with results reported in Fig. 5. Dust results in a smaller amount of the observed layers, according to the retrievals of both algorithms. Finally, although Thessaloniki is a coastal site, the maritime layers are rare, presumably due to the mixing with other aerosol types. These results are in agreement with the findings of Siomos et al. (2018).

Although each automated classification algorithm has important differences acknowledged above, the comparison showed an overall good agreement for the four defined aerosol classes. The convergence of the two different methods on the same type can be regarded as a signature of reliability. An almost perfect score was found for the PollutedSmoke category, followed by the Dust one, given that the dust class is well defined for both typing schemes, as the physical properties of dust particles differentiate from the other three classes. Considering the mismatches in the CleanContinental category, good agreement is found. By contrast, the maritime category is defined in a different way for the two automated algorithms. The EARLINET Mahalanobis distance-based typing algorithm considers maritime layers mixed with other aerosol types, whereas for NATALI the mixing is negligible and the aerosol type refers to pure maritime aerosol. The absence of measurements for such kinds of particles also did not allow a direct assessment of the pure marine particle synthetic data into the NATALI algorithm itself. The case typed as Maritime by NATALI is identified as CleanContinental: this is because of the different lidar ratio at $532 \mathrm{~nm}$ and backscatter Ångström-related values allowed in the NATALI scheme which are recognized by the EARLINET Mahalanobis distance-based typing method as a signature for CleanContinental types (Table 2).

Discussion of the mismatch cases is extremely important for understanding the limitations of the assumptions behind the two schemes and provides a useful dataset to investigate the causes, which will help to potentially improve the typing methods. In what follows, the NATALI aerosol model dataset is ingested into the EARLINET Mahalanobis distance-based typing algorithm with the aim of understanding the differences in the aerosol definition: 259407 out of 424236 instances $(61 \%)$ were typed by the EARLINET Mahalanobis distance-based typing algorithm. The untyped instances were discarded by the algorithm owing to a distance-threshold filter and a distance-similarity filter (see Sect. 3.2). The results of the application of the EARLINET Mahalanobis distancebased method to the modeled reference classes of NATALI are presented in Fig. 6. Each percentage is defined here as follows: the denominator in each column is the number of NATALI samples for a given type, and the numerator is the 


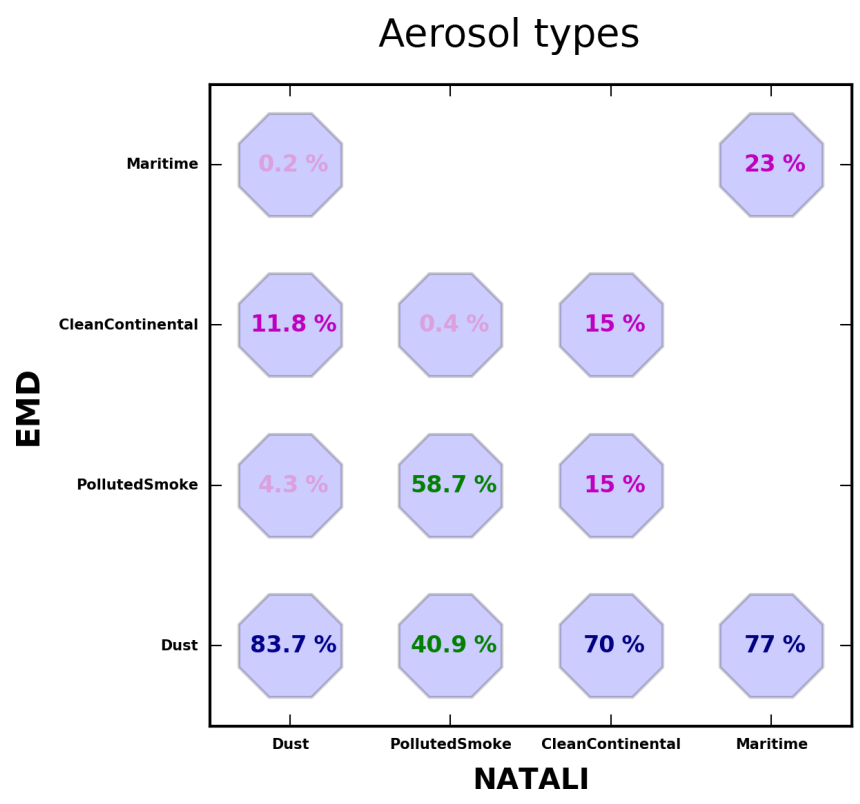

Figure 6. Typing score of each aerosol class derived by the EARLINET Mahalanobis distance-based typing algorithm (EMD) when applied to the NATALI modeled dataset (total of 259407 cases). The denominator in each column is the number of NATALI samples for a given type, and the numerator is the number of the EARLINET Mahalanobis distance-based classifications for the same sample.

number of the EARLINET Mahalanobis distance-based classifications for the same sample.

Fair agreement is found for the NATALI synthetic datasets of the Dust and PollutedSmoke categories. In particular, Dust reached agreement of $83.7 \%$ (100 166 typed over 119650). This result is very good considering that up to $30 \%$ of the aerosol class contains mixtures. For PollutedSmoke, the majority of the synthetic data, corresponding to 48180 instances from a total typed of 82041 (58.7\%), are classified as PollutedSmoke. For the CleanContinental type, the agreement is poor (15\%), as only 7605 over 52058 were correctly classified and the majority of the instances (36552) are typed as Dust $(70 \%)$. This Dust-CleanContinental mismatch is confirmed also by the $11.8 \%$ of the NATALI reference dust cases that are typed as CleanContinental by the EARLINET Mahalanobis distance-based typing method. Furthermore, 7901 of the instances (15\%) are classified as PollutedSmoke. Finally, the agreement for Maritime is $23 \%$ of the cases (1319 from a total of 5658 cases), indicating the different class definitions as well as the big spread of the NATALI maritime model that causes the EARLINET Mahalanobis distance-based typing algorithm to misclassify those data.

Despite the important differences found in the setup of the two methods, a very good agreement is achieved when the algorithms are applied to the EARLINET Thessaloniki dataset as shown in Fig. 7. For PollutedSmoke and CleanContinental the accuracy reached $88 \%$ (the common number of typed layers as PollutedSmoke from both algorithms to the total

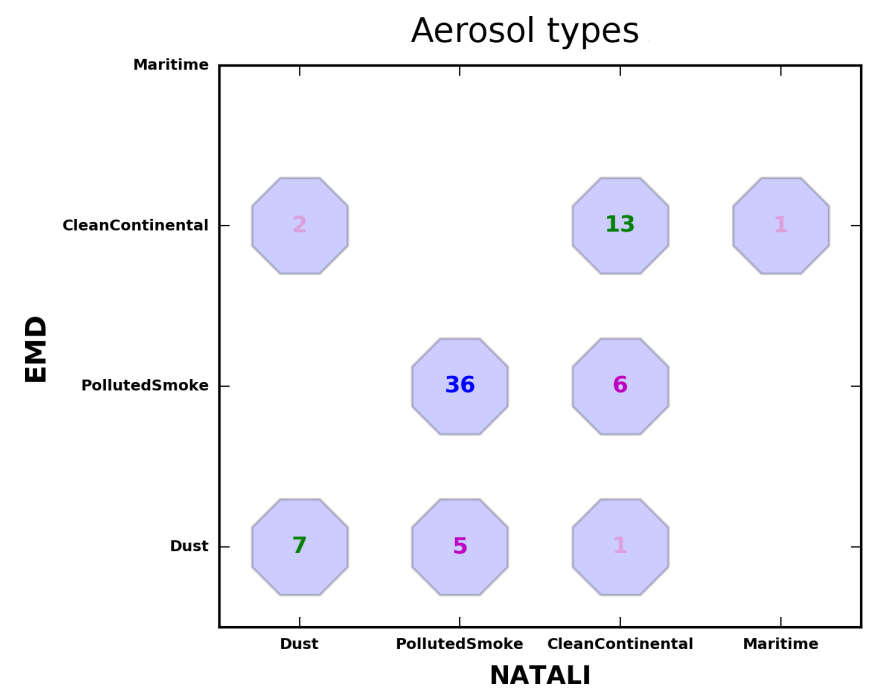

Figure 7. Number of cases per aerosol type derived by the two algorithms (EARLINET Mahalanobis distance-based typing algorithm - EMD and NATALI) for the period 2012-1015 (71 cases).

layers typed as PollutedSmoke from NATALI) and $65 \%$ (the common number of typed layers as CleanContinental from both algorithms to the total layers typed as CleanContinental from NATALI), respectively. A good performance is also found for the Dust category $(78 \%)$. It is obvious that the additional information of the particle depolarization ratio will further improve the performance of the automated typing algorithms in distinguishing dust particles from other aerosol types. An unsatisfactory agreement is observed for Maritime, which is the aerosol type less encountered over Thessaloniki. Overall, there were 15 cases (on the Thessaloniki dataset) where the two methods provided different typing results. There are seven cases typed as CleanContinental aerosol by NATALI and PollutedSmoke or CleanContinental by EMD, five cases typed as PollutedSmoke by NATALI and Dust by EMD, two cases typed as Dust by NATALI and CleanContinental by EMD and one case typed as Maritime by NATALI and CleanContinental by EMD. These mismatches are illustrated in Fig. 7. In order to understand these differences we highlight some critical issues relevant to the type definitions of the two methods, based on Nicolae et al. (2018) and Papagiannopoulos et al. (2018).

- CleanContinental. The contribution of the Soot component in the chemical composition of the Cleancontinental category allows higher lidar ratio values at $532 \mathrm{~nm}$ $(52-53 \mathrm{sr})$ in the NATALI scheme. Consequently, layers recognized by NATALI as CleanContinental ones in the EARLINET Mahalanobis distance-based typing method are attributed as the signature for PollutedSmoke or Dust (Fig. 7).

- Marine. As observations of pure maritime particles are quite scarce within EARLINET and, generally, when 
these particles are observed their characteristics are far from pristine, the Maritime category for the EARLINET Mahalanobis distance typing algorithm corresponds to mixed maritime layers. This is different from the pure maritime category that NATALI identifies. Lower lidar ratio values for $532 \mathrm{~nm}(19-25 \mathrm{sr})$ are defined in the NATALI software for the identification of marine layers, in contrast to the higher ones (16-32 sr) allowed in the EARLINET Mahalanobis distance typing algorithm.

- Dust. Higher values of the lidar ratio at $532 \mathrm{~nm}$ are allowed for the EARLINET Mahalanobis distance typing algorithm in identifying dust particles (41-63 sr), considering all dust-like aerosol types as one category, while NATALI allows values corresponding to more pure cases (44-49 sr). Therefore, a number of Dust recognitions are attributed to PollutedSmoke particles (six cases) or CleanContinental particles (one case) in the NATALI output.

- PollutedSmoke. An almost perfect score is found for the PollutedSmoke category. This can be attributed to the similar reference values attributed by both typing algorithms. The values of the lidar ratio at $532 \mathrm{~nm}$ allowed for NATALI are in the range of 62-92 sr (ContinentalPolluted and Smoke) and the ones allowed in the EARLINET Mahalanobis distance typing algorithm are in the range of 50-97 sr.

As discussed above, the ability and performance of both typing methods strongly depend on the differences in the reference aerosol classes' definition and the selection of the range thresholds applied to the intensive optical properties. The latter follow a different approach in the two typing schemes (they are linked with uncertainties in the NATALI algorithm and with the normalized probability based on the calculated distances in the Mahalanobis distance typing algorithm).

\section{Summary and conclusions}

In this study, two automated typing methods are used to obtain the dominant aerosol type using optical properties, measured by a multiwavelength Raman lidar over Thessaloniki. The application of the automatic classification methods in three case studies shows consistent results when compared against manually classified EARLINET data. Additionally, all Raman measurements for the period 2012 to 2015 are analyzed and a coarse aerosol classification analysis is made. The classification analysis covers the four major aerosol classes, representing conditions in the area of Thessaloniki, i.e., Dust, Maritime, PollutedSmoke and CleanContinental.

Both classification schemes indicate the PollutedSmoke and CleanContinental categories as the main sources of the aerosol layers observed in 3 years of measurements over
Thessaloniki, while Dust accounts for about $10 \%-17 \%$ of the cases, and Maritime particles are rarely observed. Remarkable agreement is found in the aerosol typing for the PollutedSmoke category ( $88 \%)$, followed by Dust $(78 \%)$, whilst fair agreement is observed for the CleanContinental category $(65 \%)$. Maritime is the worst-performing category, underlining the need for further investigation of the identification and validation of optical property thresholds to identify sea salt aerosol. The convergence of the two different methods on the same type can be regarded as a signature of reliability, while differences can be ascribed to the different aerosol-type definition. Moreover, despite the differences in the optical property thresholds allowed in each typing scheme, many of these thresholds do overlap (especially in the low-resolution mode). This might result in allowing typing into multiple categories. In general, it is worth mentioning that, as demonstrated in Nicolae et al. (2018) and Papagiannopoulos et al. (2018), the availability of the particle linear depolarization ratio improves the predictive accuracy of both methods. Its availability could enhance the strength of correct predictions, especially for the dust particle recognition, and could lead to the increase in the number of detected types (high-resolution typing) for both algorithms. It should also be mentioned that the success rate of the aerosol classification schemes (and thus their comparability) is largely dependent on the uncertainties of the optical properties and the threshold criteria defined. Future analysis comparing the two typing schemes on the high-resolution mode, as well as further application to other lidar stations with more complex locations and topography, is ongoing work for determining the validity of the comparison made in this study.

Overall, we conclude that the application of these typing techniques could contribute to the improvement of the model treatment and to a better exploitation of the present and future data from satellite remote sensing for aerosol classification schemes. Assessments of the adaptability of the presented aerosol-type classification schemes to future satellite missions are ongoing work. Considering that up to now, there has been no well-established method to provide correct results under every condition, the systematic and full comparison of different methods is the only way to have a better insight into the possibility of inferring the aerosol source from the observed optical properties. Additionally, the modularity of the EARLINET Single Calculus Chain tool offers the possibility to implement aerosol typing procedures for automatically providing the aerosol typing information. A comparison between the two existing typing schemes that make use of the aerosol optical properties could be rather useful, as it will allow on the one hand the optimization of aerosol typing models and on the other hand the definition of the aerosol types used and the selection of the reference dataset.

Code and data availability. The lidar data used in this study are available upon registration at http://data.earlinet.org (last access: 
20 August 2019) and the CERA database, accessible using the CERA data portal (https://cera-www.dkrz.de/WDCC/ui/cerasearch/ entry?acronym=EARLINET_Al1_2000-2015, last access: 20 August 2019). The NATALI algorithm is publicly available at http://natali.inoe.ro/resources.html/software (last access: $20 \mathrm{Au}$ gust 2019). The EARLINET distance-based typing algorithm and related reference datasets will soon be available at http://earlinet.org (last access: 20 August 2019).

Author contributions. DB, NS, and KAV performed and processed lidar measurements during the period 2012-2015. NP developed the EARLINET Mahalanobis distance-based typing algorithm. DN developed the NATALI aerosol typing algorithm. KM carried out the processing of lidar measurements with the EARLINET Mahalanobis distance-based typing algorithm. KAV carried out the processing of lidar measurements with the NATALI algorithm and prepared the figures. LM reviewed parts of the comparison of the two algorithms. DB is the PI of the lidar station and directed the preparation of the manuscript. KAV prepared the manuscript with contributions from all the co-authors.

Competing interests. The authors declare that they have no conflict of interest.

Special issue statement. This article is part of the special issue "EARLINET aerosol profiling: contributions to atmospheric and climate research". It is not associated with a conference.

Financial support. This research has been supported by the Horizon 2020 Framework Programme (grant no. ECARS (692014)). The research leading to these results has received funding from the European Union's Horizon 2020 research and innovation program for Societal challenges - smart, green and integrated transport, under grant agreement no. 723986 (project EUNADICS - AV - European Natural Disaster Coordination and Information System for Aviation). Kalliopi Artemis Voudouri acknowledges the support of the General Secretariat for Research and Technology (GSRT) and the Hellenic Foundation for Research and Innovation (HFRI), Scholarship code: 95041. The financial supports for EARLINET in the ACTRIS Research Infrastructure Project by the European Union's Horizon 2020 research and innovation program under grant agreement no. 654169 in the Seventh Framework Programme (FP7/2007-2013) and the ECARS project (East European Centre for Atmospheric Remote Sensing), under grant agreement no. 602014 , ACTRIS-2 project, are gratefully acknowledged. Further financial support is provided by the Romanian Ministry of Research and Innovation throughout the Core National Program no. 33N/PN2018.

Review statement. This paper was edited by Eduardo Landulfo and reviewed by four anonymous referees.

\section{References}

Amiridis, V., Balis, D. S., Kazadzis, S., Bais, A., Giannakaki, E., Papayannis, A., and Zerefos, C.: Four-year aerosol observations with a Raman lidar at Thessaloniki, Greece, in the framework of European Aerosol Research Lidar Network (EARLINET), J. Geophys. Res.-Atmos., 110, D21203, https://doi.org/10.1029/2005JD006190, 2005.

Amiridis, V., Balis, D. S., Giannakaki, E., Stohl, A., Kazadzis, S., Koukouli, M. E., and Zanis, P.: Optical characteristics of biomass burning aerosols over Southeastern Europe determined from UVRaman lidar measurements, Atmos. Chem. Phys., 9, 2431-2440, https://doi.org/10.5194/acp-9-2431-2009, 2009.

Amiridis, V., Marinou, E., Tsekeri, A., Wandinger, U., Schwarz, A., Giannakaki, E., Mamouri, R., Kokkalis, P., Binietoglou, I., Solomos, S., Herekakis, T., Kazadzis, S., Gerasopoulos, E., Proestakis, E., Kottas, M., Balis, D., Papayannis, A., Kontoes, C., Kourtidis, K., Papagiannopoulos, N., Mona, L., Pappalardo, G., Le Rille, O., and Ansmann, A.: LIVAS: a 3-D multi-wavelength aerosol/cloud database based on CALIPSO and EARLINET, Atmos. Chem. Phys., 15, 7127-7153, https://doi.org/10.5194/acp15-7127-2015, 2015.

Ansmann, A., Wagner, F., Müller, D., Althausen, D., Herber, A., von Hoyningen-Huene, W., and Wandinger, U.: European pollution outbreaks during ACE 2: Optical particle properties inferred from multiwavelength lidar and star-Sun photometry, J. Geophys. Res., 107, 4259, https://doi.org/10.1029/2001JD001109, 2002.

Ansmann, A., Bosenberg, J., Chaikovsky, A., Cameron, A., Eckhardt, S., Eixmann, R., Freudenthaler, V., Ginoux, P., Komguem, P., Linne, H., Angel Lopez Marquez, M., Matthias, V., Mattis, I., Mitev, V., Müller, D., Music, S., Nickovic, S., Pelon, J., Sauvage, L., Sobolewsky, P., Srivastava, M. K., Stohl, A., Torres, O., Vaughan, G., Wandinger, U., and Wiegner, M.: Long-range transport of Saharan dust to northern Europe: The 11-16 October 2001 outbreak observed with EARLINET, J. Geophys. Res., 108, 4783, https://doi.org/10.1029/2003JD003757, 2003

Ansmann, A., Mattis, I., Müller, D., Wandinger, U., Radlach, M., Althausen, D., and Damoah, R.: Ice formation in Saharan dust over central Europe observed with temperature/humidity/aerosol Raman lidar, J. Geophys. Res., 110, D18S12, https://doi.org/10.1029/2004JD005000, 2005.

Ansmann, A., Petzold, A., Kandler, K., Tegen, I., Wendisch, M., Müller, D., Weinzierl, B., Müller, T., and Heintzenberg, J.: Saharan Mineral Dust Experiments SAMUM-1 and SAMUM-2: what have we learned?, Tellus B, 63, 403-429, https://doi.org/10.1111/j.1600-0889.2011.00555.x, 2011.

Baars, H., Ansmann, A., Althausen, D., Engelmann, R., Heese, B., Müller, D., Artaxo, P., Paixao, M., Pauliquevis, M., and Souza, R.: Aerosol profiling with lidar in the Amazon Basin during the wet and dry season, J. Geophys. Res., 117, D21201, https://doi.org/10.1029/2012JD018338, 2012.

Baars, H., Kanitz, T., Engelmann, R., Althausen, D., Heese, B., Komppula, M., Preißler, J., Tesche, M., Ansmann, A., Wandinger, U., Lim, J.-H., Ahn, J. Y., Stachlewska, I. S., Amiridis, V., Marinou, E., Seifert, P., Hofer, J., Skupin, A., Schneider, F., Bohlmann, S., Foth, A., Bley, S., Pfüller, A., Giannakaki, E., Lihavainen, H., Viisanen, Y., Hooda, R. K., Pereira, S. N., Bortoli, D., Wagner, F., Mattis, I., Janicka, L., Markowicz, K. M., Achtert, P., Artaxo, P., Pauliquevis, T., Souza, R. A. F., 
Sharma, V. P., van Zyl, P. G., Beukes, J. P., Sun, J., Rohwer, E. G., Deng, R., Mamouri, R.-E., and Zamorano, F.: An overview of the first decade of PollyNET: an emerging network of automated Raman-polarization lidars for continuous aerosol profiling, Atmos. Chem. Phys., 16, 5111-5137, https://doi.org/10.5194/acp16-5111-2016, 2016.

Balis, D., Amiridis, V., Zerefos, C., Gerasopoulos, E., Andreae, M., Zanis, P., Kazantzidis, A., Kazadzis, S., and Papayannis, A.: Raman lidar and sun photometric measurements of aerosol optical properties over Thessaloniki, Greece during a biomass burning episode, Atmos. Environ., 37, 4529-4538, https://doi.org/10.1016/S1352-2310(03)00581-8, 2003.

Balis, D., Amiridis, V., Nickovic, S., Papayannis, A., and Zerefos, C.: Optical properties of Saharan dust layers as detected by a Raman lidar at Thesaloniki, Greece, Geophys. Res. Lett., 31, L13104, https://doi.org/10.1029/2004GL019881, 2004.

Basart, S., Pérez, C., Nickovic, S., Cuevas, E., and Baldasano, J.: Development and evaluation of the BSCDREAM8b dust regional model over Northern Africa, the Mediterranean and the Middle East, Tellus B, 64, 18539, https://doi.org/10.3402/tellusb.v64i0.18539, 2012b.

Belegante, L., Talianu, C., Nemuc, A., and Nicolae, D.: Detection of local weather events from multiwavelength lidar measurements during the EARLI09 campaign, Rom. J. Phys., 56, 484-494, 2011.

Belegante, L., Nicolae, D., Nemuc, A., Talianu, C., and Derognat, C.: Retrieval of the boundary layer height from active and passive remote sensors. Comparison with a NWP model, Ac. Geophys., 62, 276-289, https://doi.org/10.2478/s11600-013-0167-4, 2014.

Binietoglou, I., Basart, S., Alados-Arboledas, L., Amiridis, V., Argyrouli, A., Baars, H., Baldasano, J. M., Balis, D., Belegante, L., Bravo-Aranda, J. A., Burlizzi, P., Carrasco, V., Chaikovsky, A., Comerón, A., D’Amico, G., Filioglou, M., Granados-Muñoz, M. J., Guerrero-Rascado, J. L., Ilic, L., Kokkalis, P., Maurizi, A., Mona, L., Monti, F., Muñoz-Porcar, C., Nicolae, D., Papayannis, A., Pappalardo, G., Pejanovic, G., Pereira, S. N., Perrone, M. R., Pietruczuk, A., Posyniak, M., Rocadenbosch, F., Rodríguez-Gómez, A., Sicard, M., Siomos, N., Szkop, A., Terradellas, E., Tsekeri, A., Vukovic, A., Wandinger, U., and Wagner, J.: A methodology for investigating dust model performance using synergistic EARLINET/AERONET dust concentration retrievals, Atmos. Meas. Tech., 8, 3577-3600, https://doi.org/10.5194/amt-8-3577-2015, 2015.

Bosenberg, J., Matthias, V., Amodeo, A., Amoiridis, V., Ansmann, A., Baldasamo, J. M., Balin, I., Balis, D., Bockmann, C., Boselli, A., Carlsson, G., Chaikovsky, A., Chourdakis, G., Comerón, A., De Tomasi, F., Eixmann, R., Freudenthaler, V., Giehl, H., Grigorov, I., Hågård, A., Iarlori, M., Kirsche, A., Kolarov, G., Komguem, L., Kreipl, S., Kumpf, W., Larchevêque, G., Linné, H., Matthey, R., Mattis, I., Mekler, A., Mironova, I., Mitev, V., Mona, L., Müller, D., Music, S., Nickovic, S., Pandolfi, M., Papayannis, A., Pappalardo, G., Pelon, J., Pérez, C., Perrone, R. M., Persson, R., Resendes, D. P., Rizi, V., Rocadenbosch, F., Rodrigues, J. A., Sauvage, L., Schneidenbach, L., Schumacher, R., Shcherbakov, V., Simeonov, V., Sobolewski, P., Spinelli, N., Stachlewska, I., Stoyanov, D., Trickl, T., Tsaknakis, G., Vaughan, G., Wandinger, U., Wang, X., Wiegner, M., Zavrtanic, M., and Zerefos, C.: EARLINET: A European Aerosol Research Lidar
Network to Establish an Aerosol Climatology, Report of the Max-Planck-Institute for Meteorology No. 348, 16-39, 2003.

Burton, S. P., Ferrare, R. A., Hostetler, C. A., Hair, J. W., Rogers, R. R., Obland, M. D., Butler, C. F., Cook, A. L., Harper, D. B., and Froyd, K. D.: Aerosol classification using airborne High Spectral Resolution Lidar measurements - methodology and examples, Atmos. Meas. Tech., 5, 73-98, https://doi.org/10.5194/amt-5-732012, 2012.

D’Amico, G., Amodeo, A., Baars, H., Binietoglou, I., Freudenthaler, V., Mattis, I., Wandinger, U., and Pappalardo, G.: EARLINET Single Calculus Chain - overview on methodology and strategy, Atmos. Meas. Tech., 8, 4891-4916, https://doi.org/10.5194/amt-8-4891-2015, 2015.

Freudenthaler, V., Esselborn, M., Wiegner, M., Heese, B., Tesche, M., Ansmann, A., Müller, D., Althausen, D., Wirth, M., Fix, A., Ehret, G., Knippertz, P., Toledano, C., Gasteiger, J. M., Garhammer, M., and Seefeldner, M.: Depolarization ratio profiling at several wavelengths in pure Saharan dust during SAMUM 2006, Tellus B, 61, 165-179, https://doi.org/10.1111/j.16000889.2008.00396.x, 2009.

Freudenthaler, V., Linné, H., Chaikovski, A., Rabus, D., and Groß, S.: EARLINET lidar quality assurance tools, Atmos. Meas. Tech. Discuss., https://doi.org/10.5194/amt-2017-395, in review, 2018.

Giannakaki, E., Balis, D. S., Amiridis, V., and Zerefos, C.: Optical properties of different aerosol types: seven years of combined Raman-elastic backscatter lidar measurements in Thessaloniki, Greece, Atmos. Meas. Tech., 3, 569-578, https://doi.org/10.5194/amt-3-569-2010, 2010.

Giannakaki, E., Pfüller, A., Korhonen, K., Mielonen, T., Laakso, L., Vakkari, V., Baars, H., Engelmann, R., Beukes, J. P., Van Zyl, P. G., Josipovic, M., Tiitta, P., Chiloane, K., Piketh, S., Lihavainen, H., Lehtinen, K. E. J., and Komppula, M.: One year of Raman lidar observations of free-tropospheric aerosol layers over South Africa, Atmos. Chem. Phys., 15, 5429-5442, https://doi.org/10.5194/acp-15-5429-2015, 2015.

Giglio, L., Schroeder, W., and Justice, C. O.: The collection 6 MODIS active fire detection algorithm and fire products, Remote Sens. Environ., 178, 31-41, 2016.

Granados-Muñoz, M. J., Navas-Guzmán, F., Guerrero-Rascado, J. L., Bravo-Aranda, J. A., Binietoglou, I., Pereira, S. N., Basart, S., Baldasano, J. M., Belegante, L., Chaikovsky, A., Comerón, A., D’Amico, G., Dubovik, O., Ilic, L., Kokkalis, P., Muñoz-Porcar, C., Nickovic, S., Nicolae, D., Olmo, F. J., Papayannis, A., Pappalardo, G., Rodríguez, A., Schepanski, K., Sicard, M., Vukovic, A., Wandinger, U., Dulac, F., and AladosArboledas, L.: Profiling of aerosol microphysical properties at several EARLINET/AERONET sites during the July 2012 ChArMEx/EMEP campaign, Atmos. Chem. Phys., 16, 70437066, https://doi.org/10.5194/acp-16-7043-2016, 2016.

Groß, S., Tesche, M., Freudenthaler, V., Toledano, C., Wiegner, M., Ansmann, A., Althausen, D., and Seefeldner, M.: Characterization of Saharan dust, Maritime aerosols and mixtures of biomassburning aerosols and dust by means of multi-wavelength depolarization and Raman lidar measurements during SAMUM 2, Tellus B, 63, 706-724, https://doi.org/10.1111/j.16000889.2011.00556.x, 2011.

Groß, S., Esselborn, M., Weinzierl, B., Wirth, M., Fix, A., and Petzold, A.: Aerosol classification by airborne high spectral reso- 
lution lidar observations, Atmos. Chem. Phys., 13, 2487-2505, https://doi.org/10.5194/acp-13-2487-2013, 2013.

Hamill, P., Giordano, M., Ward, C., Giles, D., and Holbein, B.: An AERONET-based aerosol classification using the Mahalanobis distance, Atmos. Environ., 140, 213-233, https://doi.org/10.1016/j.atmosenv.2016.06.002, 2016.

Hess, M., Koepke, P., and Schult, I.: Optical properties of aerosols and clouds: The software package OPAC, B. Am. Meteorol. Soc., 79, 831-844, https://doi.org/10.1175/15200477(1998)0792.0.CO;2, 1998.

Illingworth, A. J., Barker, H. W., Beljaars, A., Ceccaldi, M., Chepfer, H., Cole, J., Delanoë, J., Domenech, C., Donovan, D. P., Fukuda, S., Hirakata, M., Hogan, R. J., Huenerbein, A., Kollias, P., Kubota, T., Nakajima, T., Nakajima, T. Y., Nishizawa, T., Ohno, Y., Okamoto, H., Oki, R., Sato, K., Satoh, M., Shephard, M., Wandinger, U., Wehr, T., and Van Zadelhoff, G.-J.: THE EARTHCARE SATELLITE: The next step forward in global measurements of clouds, aerosols, precipitation and radiation, B. Am. Meteorol. Soc., 96, 1311-1332, https://doi.org/10.1175/BAMS-D-12-00227.1, 2015.

Mahalanobis, P. C.: On the generalized distance in statistics, Proceedings of the National Institute of Science of India, 12, 49-55, 1936.

Mamouri, R. E. and Ansmann, A.: Fine and coarse dust separation with polarization lidar, Atmos. Meas. Tech., 7, 3717-3735, https://doi.org/10.5194/amt-7-3717-2014, 2014.

Marinou, E., Amiridis, V., Binietoglou, I., Tsikerdekis, A., Solomos, S., Proestakis, E., Konsta, D., Papagiannopoulos, N., Tsekeri, A., Vlastou, G., Zanis, P., Balis, D., Wandinger, U., and Ansmann, A.: Three-dimensional evolution of Saharan dust transport towards Europe based on a 9-year EARLINEToptimized CALIPSO dataset, Atmos. Chem. Phys., 17, 58935919, https://doi.org/10.5194/acp-17-5893-2017, 2017.

Matthias, V. and Bosenberg, J.: Aerosol climatology for the planetary boundary layer derived from regular lidar measurements, Atmos. Res., 63, 221-245, https://doi.org/10.1016/S01698095(02)00043-1, 2002.

Mattis, I., Ansmann, A., Mueller, D., Wandinger, U., and Althausen, D.: Multiyear aerosol observations with dual-wavelength Raman lidar in the framework of EARLINET, J. Geophys. Res.-Atmos., 109, D13203, https://doi.org/10.1029/2004jd004600, 2004.

Mona, L., Amodeo, A., D’Amico, G., Giunta, A., Madonna, F., and Pappalardo, G.: Multi-wavelength Raman lidar observations of the Eyjafjallajökull volcanic cloud over Potenza, southern Italy, Atmos. Chem. Phys., 12, 2229-2244, https://doi.org/10.5194/acp-12-2229-2012, 2012.

Mona, L., Papagiannopoulos, N., Basart, S., Baldasano, J., Binietoglou, I., Cornacchia, C., and Pappalardo, G.: EARLINET dust observations vs. BSC-DREAM8b modeled profiles: 12year-long systematic comparison at Potenza, Italy, Atmos. Chem. Phys., 14, 8781-8793, https://doi.org/10.5194/acp-148781-2014, 2014.

Mona, L., Kahn, R., Papagiannopoulos, N., Pappalardo, G., and Holzer-Popp, T.: Aerosol typing-key information from aerosol satellite measurements, European Aerosol Conference, Milan, Italy, 6-11 September 2015, available at: https://geko. promeeting.it/abstract/DEF/Poster/2AAP_P094.pdf (last access: 20 August 2019), 2015.
Müller, D., Mattis, I., Wandinger, U., Ansmann, A., Althausen, D., and Stohl, A.: Raman lidar observations of aged Siberian and Canadian forest fire smoke in the free troposphere over Germany in 2003: Micro-physical particle characterization, J. Geophys. Res., 110, D17201, https://doi.org/10.1029/2004JD005756, 2005.

Müller, D., Ansmann, A., Mattis, I., Tesche, M., Wandinger, U., Althausen, D., and Pisani, G.: Aerosol-type-dependent lidar ratios observed with Raman lidar, J. Geophys. Res., 112, D16202, https://doi.org/10.1029/2006JD008292, 2007.

Nicolae, D., Nemuc, A., Müller, D., Talianu, C., Vasilescu, J., Belegante, L., and Kolgotin, A.: Characterization of fresh and aged biomass burning events using multiwavelength Raman lidar and mass spectrometry, J. Geophys. Res.-Atmos., 118, 2956-2965, https://doi.org/10.1002/jgrd.50324, 2013.

Nicolae, D., Vasilescu, J., Talianu, C., and Dandocsi, A.: Independent Retrieval of Aerosol Type From Lidar, EPJ Web Conf., 119, 18002, https://doi.org/10.1051/epjconf/201611918002, 2016.

Nicolae, D., Vasilescu, J., Talianu, C., Binietoglou, I., Nicolae, V., Andrei, S., and Antonescu, B.: A neural network aerosol-typing algorithm based on lidar data, Atmos. Chem. Phys., 18, 1451114537, https://doi.org/10.5194/acp-18-14511-2018, 2018.

Omar, A. H., Winker, D. M., Kittaka, C., Vaughan, M. A., Liu, Z., Hu, Y., Trepte, C. R., Rogers, R. R., Ferrare, R. A., Lee, K.-P., Kuehn, R. E., and Hostetler, C. A.: The CALIPSO automated aerosol classification and lidar ratio selection algorithm, J. Atmos. Ocean. Tech., 26, 1994-2014, https://doi.org/10.1175/2009JTECH1231.1, 2009.

Papagiannopoulos, N., Mona, L., Alados-Arboledas, L., Amiridis, V., Baars, H., Binietoglou, I., Bortoli, D., D’Amico, G., Giunta, A., Guerrero-Rascado, J. L., Schwarz, A., Pereira, S., Spinelli, N., Wandinger, U., Wang, X., and Pappalardo, G.: CALIPSO climatological products: evaluation and suggestions from EARLINET, Atmos. Chem. Phys., 16, 2341-2357, https://doi.org/10.5194/acp-16-2341-2016, 2016.

Papagiannopoulos, N., Mona, L., Amodeo, A., D’ Amico, G., Gumà Claramunt, P., Pappalardo, G., Alados-Arboledas, L., GuerreroRascado, J. L., Amiridis, V., Kokkalis, P., Apituley, A., Baars, H., Schwarz, A., Wandinger, U., Binietoglou, I., Nicolae, D., Bortoli, D., Comerón, A., Rodríguez-Gómez, A., Sicard, M., Papayannis, A., and Wiegner, M.: An automatic observation-based aerosol typing method for EARLINET, Atmos. Chem. Phys., 18, 1587915901, https://doi.org/10.5194/acp-18-15879-2018, 2018.

Papayannis, A., Amiridis, V., Mona, L., Tsaknakis, G., Balis, D., Bosenberg, J., Chaikovski, A., De Tomasi, F., Grigorov, I., Mattis, I., Mitev, V., Müller, D., Nickovic, S., Pérez C., Pietruczuk, A., Pisani, G., Ravetta, F., Rizi, V., Sicard, M., Trickl, T., Wiegner, M., Gerding, M., Mamouri, R. E., D'Amico, G., and Pappalardo, G.: Systematic lidar observations of Saharan dust over Europe in the frame of EARLINET (2000-2002), J. Geophys. Res., 113, D10204, https://doi.org/10.1029/2007JD009028, 2008.

Papayannis, A., Mamouri, R.-E., Vassilis, A., Giannakaki, E., Veselovskii, I., Kokkalis, P., Tsaknakis, G., Balis, D., Kristiansen, N., Stohl, A., Korenskiy, M., and Allakhverdiev, K.: Optical properties and vertical extension of aged ash layers over the Eastern Mediterranean as observed by Raman lidars during the Eyjafjallajökull eruption in May 2010, Atmos. Environ., 48, 5665, https://doi.org/10.1016/j.atmosenv.2011.08.037, 2012. 
Pappalardo, G., Amodeo, A., Mona, L., Pandolfi, M., Pergola, N., and Cuomo, V.: Raman lidar observations of aerosol emitted during the 2002 Etna eruption, Geophys. Res. Lett., 31, L05120, https://doi.org/10.1029/2003GL019073, 2004.

Pappalardo, G., Mona, L., D’Amico, G., Wandinger, U., Adam, M., Amodeo, A., Ansmann, A., Apituley, A., Alados Arboledas, L., Balis, D., Boselli, A., Bravo-Aranda, J. A., Chaikovsky, A., Comeron, A., Cuesta, J., De Tomasi, F., Freudenthaler, V., Gausa, M., Giannakaki, E., Giehl, H., Giunta, A., Grigorov, I., Groß, S., Haeffelin, M., Hiebsch, A., Iarlori, M., Lange, D., Linné, H., Madonna, F., Mattis, I., Mamouri, R.-E., McAuliffe, M. A. P., Mitev, V., Molero, F., Navas-Guzman, F., Nicolae, D., Papayannis, A., Perrone, M. R., Pietras, C., Pietruczuk, A., Pisani, G., Preißler, J., Pujadas, M., Rizi, V., Ruth, A. A., Schmidt, J., Schnell, F., Seifert, P., Serikov, I., Sicard, M., Simeonov, V., Spinelli, N., Stebel, K., Tesche, M., Trickl, T., Wang, X., Wagner, F., Wiegner, M., and Wilson, K. M.: Four-dimensional distribution of the 2010 Eyjafjallajökull volcanic cloud over Europe observed by EARLINET, Atmos. Chem. Phys., 13, 4429-4450, https://doi.org/10.5194/acp-13-4429-2013, 2013.

Pappalardo, G., Amodeo, A., Apituley, A., Comeron, A., Freudenthaler, V., Linné, H., Ansmann, A., Bösenberg, J., D’Amico, G., Mattis, I., Mona, L., Wandinger, U., Amiridis, V., AladosArboledas, L., Nicolae, D., and Wiegner, M.: EARLINET: towards an advanced sustainable European aerosol lidar network, Atmos. Meas. Tech., 7, 2389-2409, https://doi.org/10.5194/amt7-2389-2014, 2014.

Russell, P. B., Kacenelenbogen, M., Livingston, J. M., Hasekamp, O. P., Burton, S. P., Schuster, G. L., Johnson, M. S., Knobelspiesse, K. D., Redemann, J., Ramachandran, S., and Holben, B.: A multiparameter aerosol classification method and its application to retrievals from spaceborne polarimetry, J. Geophys. Res.-Atmos., 119, 9838-9863, https://doi.org/10.1002/2013JD021411, 2014.

Sawamura, P., Vernier, J. P., Barnes, J. E., Berkoff, T. A., Welton, E. J., Alados-Arboledas, L., Navas-Guzmán, F., Pappalardo, G., Mona, L., Madonna, F., Lange, D., Sicard, M., GodinBeekmann, S., Payen, G., Wang, Z., Hu, S., Tripathi, S. N., Cordoba-Jabonero, C., and Hoff, R. M.: Stratospheric AOD after the 2011 eruption of Nabro volcano measured by lidars over the Northern Hemisphere, Environ. Res. Lett., 7, 034013, https://doi.org/10.1088/1748-9326/7/3/034013, 2012.

Schmeisser, L., Andrews, E., Ogren, J. A., Sheridan, P., Jefferson, A., Sharma, S., Kim, J. E., Sherman, J. P., Sorribas, M., Kalapov, I., Arsov, T., Angelov, C., Mayol-Bracero, O. L., Labuschagne, C., Kim, S.-W., Hoffer, A., Lin, N.-H., Chia, H.-P., Bergin, M., Sun, J., Liu, P., and Wu, H.: Classifying aerosol type using in situ surface spectral aerosol optical properties, Atmos. Chem. Phys., 17, 12097-12120, https://doi.org/10.5194/acp-17-120972017, 2017.

Schwarz, A.: Aerosol typing over Europe and its benefits for the CALIPSO and EarthCARE missions - statistical analysis based on multiwavelength aerosol lidar measurements from ground-based EARLINET stations and comparison to spaceborne CALIPSO data, PhD thesis, University of Leipzig, Germany, 2016.

Sicard, M., D’Amico, G., Comerón, A., Mona, L., AladosArboledas, L., Amodeo, A., Baars, H., Baldasano, J. M., Belegante, L., Binietoglou, I., Bravo-Aranda, J. A., Fernández, A. J.,
Fréville, P., García-Vizcaíno, D., Giunta, A., Granados-Muñoz, M. J., Guerrero-Rascado, J. L., Hadjimitsis, D., Haefele, A., Hervo, M., Iarlori, M., Kokkalis, P., Lange, D., Mamouri, R. E., Mattis, I., Molero, F., Montoux, N., Muñoz, A., Muñoz Porcar, C., Navas-Guzmán, F., Nicolae, D., Nisantzi, A., Papagiannopoulos, N., Papayannis, A., Pereira, S., Preißler, J., Pujadas, M., Rizi, V., Rocadenbosch, F., Sellegri, K., Simeonov, V., Tsaknakis, G., Wagner, F., and Pappalardo, G.: EARLINET: potential operationality of a research network, Atmos. Meas. Tech., 8, 4587-4613, https://doi.org/10.5194/amt-8-4587-201, 2015.

Siomos, N.: Climatology and classification of the optical and microphysical properties of aerosols using ground - based remote sensing techniques (Doctoral dissertation), available at: http:// hdl.handle.net/10442/hedi/45104 (last access: 20 August 2019), 2018.

Siomos, N., Balis, D. S., Voudouri, K. A., Giannakaki, E., Filioglou, M., Amiridis, V., Papayannis, A., and Fragkos, K.: Are EARLINET and AERONET climatologies consistent? The case of Thessaloniki, Greece, Atmos. Chem. Phys., 18, 11885-11903, https://doi.org/10.5194/acp-18-11885-2018, 2018a.

Siomos, N., Fountoulakis, I., Natsis, A., Karagiozidis, D., Drosoglou, T., Voudouri, K. A., Bais, A., and Balis, D.: Aerosol classification based on the synergy of Brewer spectrophotometer and sunphotometer measurements, 14th International Conference on Meteorology, Climatology and Atmospheric Physics, available at: http://comecap2018.gr/wp-content/uploads/2019/ 03/COMECAP-BOA-final-revised.pdf (last access: $20 \mathrm{Au}-$ gust 2019), 2018b.

Stein, A. F., Draxler, R. R., Rolph, G. D., Stunder, B. J. B., Cohen, M. D., and Ngan, F.: NOAA's HYSPLIT atmospheric transport and dispersion modeling system, B. Am. Meteorol. Soc., 96, 2059-2077, https://doi.org/10.1175/BAMS-D-14-00110.1, 2015

Tesche, M., Ansmann, A., Müller, D., Althausen, D., Engelmann, R., Freudenthaler, V., and Groß, S.: Vertically resolved separation of dust and smoke over Cape Verde using multiwavelength Raman and polarization lidars during Saharan Mineral Dust Experiment 2008, J. Geophys. Res., 114, D13202, https://doi.org/10.1029/2009JD011862, 2009a.

Tesche, M., Ansmann, A., Müller, D., Althausen, D., Mattis, I., Heese, B., Freudenthaler, V., Wiegner, M., Esselborn, M., Pisani, G., and Knippertz, P.: Vertical profiling of Saharan dust with Raman lidars and airborne HSRL in southern Morocco during SAMUM, Tellus B, 61, 144-164, https://doi.org/10.1111/j.16000889.2008.00390.x, 2009b.

Tesche, M., Detlef, M., Groß, S., Ansmann, A., Althausen, D., Freudenthaler, V., Weinzierl, B., Veira, A., and Petzold, A.: Optical and microphysical properties of smoke over Cape Verde inferred from multiwavelength lidar measurements, Tellus B, 63 , 677-694, https://doi.org/10.3402/tellusb.v63i4.16362, 2011a.

Tesche, M., Groß, S., Ansmann, A., Müller, D., Althausen, D., Freudenthaler, V., and Esselborn, M.: Profiling of Saharan dust and biomass burning smoke with multiwavelength polarization Raman lidar at Cape Verde, Tellus B, 63, 649-676, https://doi.org/10.1111/j.1600-0889.2011.00548.x, 2011b.

Wandinger, U., Baars, H., Engelmann, R., Hünerbein, A., Horn, S., Kanitz, T., Donovan, D., van Zadelhoff, G.-J., Daou, D., Fischer, J., von Bismarck, J., Filipitsch, F., Docter, N., Eisinger, M., Lajas, D., and Wehr, T.: HETEAC: The Aerosol Classi- 
fication Model for Earth-CARE, EPJ Web Conf., 119, 01004, https://doi.org/10.1051/epjconf/201611901004, 2016.

Yorks, J. E., Palm, S. P., McGill, M. J., Hlavka, D. L., Hart, W. D., Selmer, P. A., and Nowottnick, E.: CATS Algorithm Theoretical Basis Document, Level 1 and Level 2 Data Products, available at: https://cats.gsfc.nasa.gov/media/docs/CATS_ATBD.pdf (last access: 20 August 2019), 2016. 